\title{
Fen Bilimleri ve İlköğretim Matematik Öğretmen Adaylarının Öz-Yeterlik İnançları ile Öz-Yeterlik Kaynaklarının İncelenmesi*
}

\section{Özge GÜN${ }^{1}$, Burçin ACAR-ŞEŞEN², Cansel AKBULUT ${ }^{3}$, Ayla ÇETİN-DİNDAR ${ }^{4}$, Zehra MOLU ${ }^{5}$}

Öz: Bu çalışmanın amacı fen bilimleri ve ilköğretim matematik öğretmen adaylarının özyeterlik inançları ve öz-yeterlik kaynaklarını öğrenim gördükleri program türü, sınıf düzeyi ve cinsiyet değişkenleri açısından incelemektir. Çalışma nicel araştırma yaklaşımlarından tarama desenine dayalı gerçekleştirilmiştir. Beş üniversitenin Fen Bilgisi ve İlköğretim Matematik Öğretmenliği programlarının üçüncü ve dördüncü sınıflarında öğrenim gören toplam 885 öğretmen adayından Öğretmen Öz-Yeterlik Ölçeği ve Öz-Yeterlik Kaynakları Ölçeği kullanılarak veri toplanmıştır. Verilerin analizinde betimsel istatistikler ile yordamsal istatistiklerden tek yönlü çok değişkenli varyans analizi (MANOVA) kullanılmıştır. Çalışma sonucunda öz-yeterlik inançları değişkenine ait alt boyutların hepsi için öğretmen adaylarının tamamının oldukça yeterli düzeyde olduğu görülmüştür. Diğer taraftan öz-yeterlik kaynakları değişkeninin alt boyutları açısından öğretmen adaylarının düzeylerinde farklılıklar gözlenmiştir. En yüksek aritmetik ortalama Sözel İkna boyutunda, en düşük ortalama ise Fizyolojik ve Duygusal Durumlar boyutunda elde edilmiştir. İncelenen değişkenlerin öğretmen adaylarının öğrenim gördükleri program türü, sınıf düzeyi ve cinsiyete göre farklılık gösterip göstermediğini test etmek için altı farklı tek yönlü MANOVA uygulanmıştır. Cinsiyete göre öz-yeterlik kaynaklarına ilişkin yapılan analiz haricinde diğer tüm analizlerde istatistiksel olarak anlamlı farklılıklar bulunmuştur.

Anahtar Kelimeler: Öz-yeterlik inanc1, öz-yeterlik kaynakları, öğretmen adayları, öğretmen eğitimi

\section{An Investigation of Pre-Service Science and Elementary Mathematics Teachers' Self- Efficacy Beliefs and Their Sources}

Abstract: The aim of this study was to investigate pre-service science and elementary mathematics teachers' self-efficacy beliefs and sources of their self-efficacy according to the program type, grade level, and gender. The study was carried out based on the survey design among quantitative research approaches. Data were collected from a total of 885 pre-service teachers who were enrolled in the third and fourth grades of Science and Elementary

\footnotetext{
${ }^{1}$ Dr. Öğr. Üyesi, Bartın Üniversitesi, Eğitim Fakültesi, Matematik ve Fen Bilimleri Eğitimi Bölümü, e-mail: ozgegun@bartin.edu.tr, Orcid No: 0000-0001-6431-3354

2 Prof. Dr., İstanbul Üniversitesi-Cerrahpaşa, Hasan Ali Yücel Eğitim Fakültesi, Matematik ve Fen Bilimleri Eğitimi Bölümü, e-mail: bsesen@istanbul.edu.tr, Orcid No: 0000-0002-1585-0441

3 Dr. Öğr. Üyesi, Tokat Gaziosmanpaşa Üniversitesi, Eğitim Fakültesi, Matematik ve Fen Bilimleri Eğitimi Bölümü, e-mail: canselkadioglu@gmail.com, Orcid No: 0000-0002-6908-1684

4 Doç. Dr., Bartın Üniversitesi, Eğitim Fakültesi, Matematik ve Fen Bilimleri Eğitimi Bölümü, e-mail: adindar@bartin.edu.tr, Orcid No: 0000-0003-3086-163X

${ }^{5}$ Dr. Öğr. Üyesi, Niğde Ömer Halisdemir Üniversitesi, Eğitim Fakültesi, Matematik ve Fen Bilimleri Eğitimi Bölümü, email: zmolu@ohu.edu.tr, Orcid No: 0000-0003-2393-9160

*Bu çalıșma, Bartın Üniversitesi Bilimsel Araștırma Projeleri Komisyonu tarafından desteklenmiștir (Proje No:2018SOS-A-015).
} 
Mathematics Education Programs from five universities, using the Teachers' Sense of Efficacy Scale and Sources of Self-Efficacy Inventory. The descriptive statistics and one-way Multivariate Analysis of Variance (MANOVA) among inferential statistics were used in the analysis of the data. As a result of the study, it was seen that all pre-service teachers were at the level of quite sufficient for all sub-dimensions of self-efficacy. On the other hand, differences were observed in pre-service teachers' levels according to the sub-dimensions of the selfefficacy sources variable. The highest mean score was obtained in the Verbal Persuasion dimension while the lowest mean score was observed in the Physiological and Emotional Arousal dimension. Six one-way MANOVAs applied to test whether the investigated variables differ according to program type, grade level, and gender. Statistically significant differences were found in all analyses except for the sources of teacher self-efficacy by gender.

Keywords: Self-efficacy beliefs, sources of self-efficacy, pre-service teachers, teacher education

\section{Giriş}

Yirmi birinci yüzyılda küreselleşmenin artan etkisi ile birlikte bilim ve teknoloji alanında hızlı değişimler yaşanmakta, işgücü ihtiyaçları sürekli değişim göstermekte ve bunun sonucu olarak günümüzdeki bilgi toplumunun ihtiyaç duyduğu bireylerin yetiştirilmesinde 21 . yüzyıl becerileri ön plana çıkmaktadır. Bu beceriler, ögrenme ve yenilikçi beceriler (yaratıcı düşünme, problem çözme becerileri gibi), bilgi, medya ve teknoloji becerileri (medya okuryazarlığı, bilgi ve iletişim teknolojileri okuryazarlığ becerileri (girişimcilik, sorumluluk becerileri gibi) olmak üzere üç ana başlık altında açıklanmaktadır (Partnership for 21st Century Learning [P21], 2007). Bireylerin 21. yy becerilerini kazanmalarında eğitim kurumlarına ve bu kurumların en önemli öğesi olan öğretmenlere büyük görev düşmektedir. Dolayısıyla, öğretmenlerin günümüzde istenilen niteliklere ilave olarak sahip olmaları gereken mesleki yeterliklerde de değişimler gözlemlenmektedir. Bu kapsamda, öğretmen öz-yeterlikleri pek çok araştırmanın odak noktası haline gelmiştir.

Öz-yeterlik, Bandura'nın (1986) öne sürdüğü Sosyal Bilişsel Kuram’ın önde gelen kavramlarından biridir. Bandura (1997, s.3), "algılanan öz-yeterliği, kişilerin olası durumları yönetmek için gerekli eylem planlarını organize etme ve uygulama yeteneklerine olan inançları" olarak tanımlamaktadır. Öz-yeterlik inançları bireylerin izlemeyi seçtikleri eylem yollarını, verilen işlerde ne kadar çaba sarf ettiklerini, engeller ve başarısızlıklar karşısında ne kadar uzun süre dayanabileceklerini ve güçlüklere karşı dirençlerini, kısacası bireyin performansını etkileyen önemli bir faktördür (Bandura, 1997). Dolayısıyla, bireylerin herhangi bir işte kendi yeterliklerine olan inançları onların başarı veya başarısızlı̆ıını belirler. $\mathrm{Bu}$ anlamda, öğretmenlerin sahip oldukları öz-yeterlikler onların etkili bir öğrenme ortamı oluşturmalarında ve 21. yy'da talep edilen insan profiline sahip öğrenci yetiştirmelerinde oldukça önemlidir.

Öz-yeterliğin göreve özgü doğası olduğunu belirten ve Bandura'nın Sosyal Bilişsel Kuram'ına dayalı olarak öğretmen öz-yeterliğini açıklayan Tschannen-Moran, Woolfolk Hoy ve Hoy (1998, s.233), öğretmen öz-yeterliğini "öğretmenin, belirli bir bağlamda, belirli bir öğretim görevini başarılı bir şekilde yerine getirmek için gerekli eylem planlarını organize etme ve yürütme konusundaki bireysel kabiliyetine olan inancı" olarak tanımlamaktadırlar. Tschannen-Moran ve diğerleri (1998), öğretmenin öz-yeterlik inancı ile sınıf ortamındaki davranışları ve öğrenci başarısı arasında sıkı bir ilişki olduğunu vurgulamaktadırlar. Tschannen-Moran ve Woolfolk Hoy (2001), öğretmen öz-yeterlik alanlarını üç başlıkta incelemektedir: Sınıf yönetimi için yeterlik, ögretim stratejileri için yeterlik ve öğrenci katılımı için yeterlik. Sınıf yönetimi için yeterlik, bir öğretmenin öğrenci davranışını yönetme ve sınıfta 
hakimiyeti kurma becerisine olan inancı ile ilgilidir. Öğretim stratejileri için yeterlik, öğretmenlerin alternatif öğretim stratejilerini kullanma, zorluk seviyesini değerlendirme ve beklenmedik durumlara çözüm bulma yeteneklerine olan inançlarını yansıtır. Öğrenci katılımı için yeterlik, bir öğretmenin öğrencileri motive etme yeteneklerine olan inancını temsil eder. Bir öğretmenin bu üç alanda sahip olduğu becerilere yönelik inancı onun öz-yeterlik inanç düzeyini göstermektedir. Yüksek öz-yeterlik inancına sahip olan öğretmenler, yeniliklere açık olma eğilimindedirler, sınıf ortamlarında daha etkili öğretim stratejilerini kullanmaya isteklidirler, dersi planlama ve yürütme becerileri yüksektir, öğrencilerin derse katılımlarını sağlamada başarılıdırlar, öğrenme çıktılarını bilirler ve öğrencilerin istenilen kazanımlara ulaşmalarında etkin rol oynarlar, mesleki tükenme olasılıkları düşüktür ve mesleklerine bağl1lıkları yüksektir (Allinder, 1994; Aloe, Amo ve Shanahan 2014; Holzberger, Philipp ve Kunter, 2013; Tschannen-Moran vd., 1998; Tschannen-Moran ve Woolfolk Hoy, 2001; Zee ve Koomen, 2016). Bu nedenle, öğretmenlerin öz-yeterlik inançlarını ve bu inançları etkileyen faktörleri belirlemek oldukça önemlidir.

Alanyazında, öğretmenlerin öz-yeterlik inançlarının nasıl gelişip kalıcı hale geldiğ $i$ Bandura'nın (1997) Sosyal Bilişsel Kuramı'nda vurguladığı karşılıklı belirleyicilik ilkesi ile açıklanmaktadır. Buna göre kişisel bir faktör olan öz-yeterlik ile kişinin davranışları ve çevresel faktörler birbirlerini karşılıklı olarak etkilemektedirler. Örneğin; yüksek öz-yeterlik inancına sahip (kişisel faktör) öğretmenler sınıflarında öğrenme güçlüğü çeken ya da düşük motivasyona sahip öğrenciler ile karşılaştıklarında (çevresel faktör) dersi o öğrenciler için ilgi çekici hale getirmek için öğretim yaklaşımlarını değiştirirler (davranışsal faktör). Öte yandan, bu çabaları (davranışsal faktör) sonrasında öğrencilerinin derse katılımının arttı̆̆ını (çevresel faktör) gözlemlediklerinde öz-yeterlik inançları (kişisel faktör) artar. Bu örnekte olduğu gibi kişisel, çevresel ve davranışsal faktörler birbirlerini çift yönlü etkilemektedir.

Sosyal Bilişsel Kuram’a göre bireyler öz-yeterlik inançlarını doğrudan yaşantılar, dolaylı yaşantılar, sözel ikna ve fizyolojik-duygusal durum kaynaklarından gelen bilgileri değerlendirerek şekillendirmektedirler (Bandura, 1986). Doğrudan yaşantılar, bireylerin özyeterlik inançlarının daha önceki kişisel deneyimleri doğrultusunda şekillenmesidir. Buna göre, bireylerin zor olarak değerlendirdikleri bir görevdeki başarılarını kendi yetenekleri ve çabaları ile açıklamaları öz-yeterlik inancı üzerinde etkili olmaktadır (Bandura, 1997). Eğer bireylerin öz-yeterlik inançları kendilerine yakın özelliklere sahip diğer bireyleri gözlemleyerek gelişiyorsa dolaylı yaşantılar kaynağı etkilidir. Birey, gözlemlediği kişinin özelliklerini kendi özellikleriyle ne kadar çok örtüştürürse dolaylı yaşantılar kaynağı da o derece güçlü olur. Bu faktör, özellikle verilen görev yeni olduğu durumlarda, öz-yeterlik inancının gelişimi üzerinde oldukça etkilidir (Bandura, 1997). Sözel ikna, güvenilir kişilerden gelen cesaretlendirici sözlerin öz-yeterlik inancını olumlu yönde etkilediği anlamına gelmektedir. Bandura (1997)'ya göre, sözel iknaların kişinin öz-yeterlik inancını değiştirme gücü, genellikle geri bildirimi sağlayan kişinin konu ile ilgili ne kadar bilgili olduğu ve güvenirliğinin yanında verilen mesajların ne kadar samimi ve eyleme özgü olduğuyla yakından ilişkilidir. Bireyin içinde bulunduğu kayg1, heyecan, yorgunluk gibi fizyolojik ve duygusal durumlar da önemli bir rol oynamaktadır. Fizyolojik ve duygusal durumların birey tarafindan hissedilme yoğunluğu bireyin öz-yeterlik inancını etkileyebilir. Orta düzeydeki bir uyarılma optimal performansa yol açmaktadır (Bandura, 1997).

Bandura'nın kuramı öğretmen öz-yeterliği açısından ele alındığında öğretmenlerin edindikleri deneyimlerin (doğrudan yaşantı) öz-yeterlik inançlarının gelişmesinde oldukça etkili olduğu görülmektedir. Bir öğretmenin, başka öğretmenleri gözlemleyerek veya model alarak kazandığı deneyimler (dolaylı yaşantı) öz-yeterlik inancının gelişmesinde doğrudan yaşantılar kadar etkili olmamaktadır (Bandura, 1997). Aynı zamanda bir öğretmenin, fikrine değer verdiği bir meslektaşı, arkadaşı veya aile bireyi tarafından kendisi hakkında yapılan 
yorumlar (sözel ikna) öğretmenin öz-yeterlik inancının oluşmasında etkili faktörlerdendir. Öğretmenin sınıf ortamında veya özel hayatında yaşadığı duygulara yönelik tepkileri (fizyolojik ve duygusal durum) öz-yeterlik inançlarını etkilemektedir. Olumlu duygular öz-yeterlik inancını artırabilir iken baş edilemeyen olumsuz duygular ise öz-yeterlik inançlarını düşürebilir. Dolayısıyla, öğretmenin sürekli başarılı deneyimler tecrübe etmesi onun öz-yeterlik inancını artırırken, yaşadığı başarısız ve üstesinden gelemediği deneyimler ise öz-yeterlik inancının düşmesine neden olabilmektedir.

Alanyazın incelendiğinde 1970'lerden itibaren öğretmen öz-yeterlik inançlarının nasıl oluştuğu ve gelişim gösterdiğine yönelik çok sayıda çalışma olduğu görülmektedir. Lortie (1975) öğretmen adaylarının, çıraklık sisteminden geçtiğini ve bu süreçte deneyimli öğretmenleri ve okul sistemini gözlemlemek ve değerlendirmek zorunda olduklarını, böylece fiilen öğretmenlik mesleğine geçmeden önce deneyim kazanmaya başladıkları için kendilerini mesleğe hazır olarak gördüklerini ve dolayısıyla öz-yeterliklerinin de yüksek olduğunu belirtmiştir. Tschannen-Moran ve Woolfolk Hoy (2007) ise öğretmenlerin öz-yeterliklerinin önce sınıf yönetimi ve öğretim stratejileri alanlarında gelişim gösterdiğini, deneyimle birlikte daha sonra öğrenci katılımı alanında ilerlemelerin olduğunu vurgulamışlardır.

Klassen, Tze, Betts ve Gordon (2011), 1998-2009 yılları arasında yapılan öğretmen özyeterlik çalışmalarını araştırmışlar ve sonuç olarak öğretmenlerin öz-yeterlik kaynaklarına ve öz-yeterliklerinin nasıl geliştiğine yeteri kadar önem verilmediğini belirtmişlerdir. Wyatt (2014) da 2005-2012 yılları arasında yayınlanmış nicel çalışmaları araştırmış ve öğretmen özyeterlik inançlarının nasıl oluştuğunu ele alan çalışmaların oldukça az olduğunun altını çizmiştir. Morris, Usher ve Chen (2017), benzer bir araştırmayı 1977-2015 yılları için gerçekleştirmiştir. Öğretmen öz-yeterlik kaynaklarına yönelik çalışmaların yoğun olarak doğrudan yaşantıların etkisine odaklandığını, sonra sırasıyla dolaylı yaşantılar, sosyal ikna ve duygusal ve fizyolojik durumlar ile ilgili çalışmaların geldiğini rapor etmişlerdir. Öğretmen adayları ile yapılan bazı çalışmalarda, doğrudan yaşantılar kaynaklı öz-yeterlik inancının okulda geçirilen zaman ile ilişkili olduğu rapor edilmiştir (Çapa Aydın ve Woolfolk Hoy, 2005; Gurvitch ve Metzler, 2009). Benzer ilişki öğretmenler için de tespit edilmiştir (Wolters ve Daugherty, 2007). Başka bir ifade ile öz-yeterlik inançları yüksek olan deneyimli öğretmenlerin kaynağı doğrudan yaşantılarıdır. Ancak, öğretmen öz-yeterliği ile mesleki deneyim arasında ilişkilerin olmadığını ortaya koyan araştırmalar da mevcuttur (Ruble, Usher ve McGrew, 2011; Tschannen-Moran ve Johnson, 2011). Doğrudan yaşantıların yanında dolaylı yaşantıların da öz-yeterlik inançlarını geliştirdiği araştırmacılar tarafindan rapor edilmiştir (Bautista, 2011; Posnanski, 2002). Örneğin, Bautista (2011) çalışmasında öğretmen adaylarının yeni teknikler öğrenirken deneyimli öğretmenlerin örnek olay videolarını izlemenin onların öz-yeterlik inançlarını yükselttiğini belirtmiştir. Aynı zamanda, çalışmalar göstermiştir ki öğretmenlerin öz-yeterlik inançları gözlem sonrası uzmanlardan aldıkları geri bildirimlerin (Palmer, 2006) yanı sıra öğrencilerden aldıkları dönütlerden (Milner, 2002) de etkilenmektedir. Duygusal ve fizyolojik durumlar açısından bakıldığında ise, öğretmen adayları, sınıf yönetimi açısından öğrencilerin istenmedik davranışları olduğunda daha çok stresli olduklarını belirtmişlerdir ve bu öğretmen adayları daha düşük öz-yeterlik inançlarına sahip olma eğilimindedirler (Klassen ve Chiu, 2010). Öğretmenlerle yapılan başka bir çalışmada ise, öğretmenlerdeki olumlu durumlar (örneğin coşku, memnuniyet, rahatlık, vb.) ile öğretmenlerin öz-yeterlik inançları arasında pozitif ilişkiler tespit edilmiştir (Salanova, Llorens ve Schaufeli, 2011).

Alanyazında öğretmen öz-yeterlik inancının değişimini araştıran çalışmalar da göze çarpmaktadır. Carleton, Fitch ve Krockover (2008), öğretmenlere bir yıllık verilen eğitim sonrasında öğretmenlerin öz-yeterlik inanç düzeylerinde ve tutumlarında artış olduğunu gözlemlemişlerdir. Bu süreçte öğretmenlerin öz-yeterlik inançlarında düşüşe neden olan üç engelin ders yükü, yoğun öğretim programı ve yüksek öğrenci sayısı olduğu saptanmıştır. Clark 
ve Newberry (2019), öğretmen adaylarının öz-yeterlik inançları ile öngörülebilir öz-yeterlik kaynakları arasındaki ilişkileri incelemek amacıyla yarı deneysel bir çalışma gerçekleştirmiştir. $\mathrm{Bu}$ amaçla, öğretmen adayları uzman öğretmen rehberliğinde gerçek sınıf ortamlarında bir dönem boyunca öğrencilere eğitim vermiş, pratikler yapmış, deneyimler kazanmış, sınıf yönetimi becerileri geliştirmişlerdir. Çalışma kapsamında doğrudan yaşantılar, dolaylı yaşantılar ve sözel ikna kaynakları incelenmiş, bu üç öz-yeterlik kaynağı arasında pozitif ve anlamlı ilişkiler saptanmış ve öğretmen adayının öz-yeterliğinin güçlü bir yordayıcısı olduğu bulunmuştur.

Araştırmalar deneyimli ve deneyimli olmayan öğretmenlerin öz-yeterlik inançları ile cinsiyet arasında oldukça küçük bir ilişki ortaya koymaktadır (Devos, Dupreiz ve Paquay, 2012; Tschannen-Moran ve Woolfolk Hoy, 2007). Bazı çalışmalar, erkek öğretmen modelinin az olmasından dolayı bu farkın kadınlar lehine olduğunu tespit etmiştir (Cheung, 2008; Fives ve Looney, 2009; Tschannen-Moran ve Johnson, 2011). Fakat bazı çalışmalar da, erkek öğretmenler lehine fark bulmuşlardır (Lumpe, Czerniak, Haney ve Beltyukova, 2012). Dolayısıyla, sosyal bir değişken olan cinsiyet farklı bağlam veya durumlarda öğretmen özyeterlik inançlarında farklı sonuçlar ortaya çıkarabilmektedir. Duygusal ve fizyolojik durumlar açısından da benzer bir belirsizlik söz konusudur; erkek öğretmenlerin sınıf ortamında daha stresli olduklarını tespit eden çalışmaların (Sabbe ve Aelterman, 2007) yanında kadın öğretmenlerin iş yükünden kaynaklı daha stresli olduklarını tespit eden çalışmalar (Klassen ve Chiu, 2010) da bulunmaktadir.

Alanyazın incelemesinde de görüldüğü üzere yeniliklere açık, mesleğine tutku ile bağlı, öğrenci katılımını destekleyen öğretimsel yaklaşımları uygulayan, öz-yeterliği yüksek öğretmenlerin yetişmesi için öncelikle onların öz-yeterlik inanç düzeylerini tespit etmek ve aynı zamanda bu inançlarına etki eden faktörleri iyi analiz etmek gerekmektedir. Bu amaçla, sunulan çalışmada, fen bilimleri ve ilköğretim matematik öğretmen adaylarının öz-yeterlik inançları ve öz-yeterlik kaynakları birlikte ele alınmış ve öğrenim görülen program türü, sınıf düzeyi ve cinsiyet değişkenleri açısından incelenmiştir. Bu doğrultuda çalışmanın problemleri ve alt problemleri aşağıdaki gibidir:

1. Fen bilimleri ve ilköğretim matematik öğretmen adaylarının öz-yeterlik inançları ve öz-yeterlik kaynakları hangi düzeydedir?

1.1 Fen bilimleri ve ilköğretim matematik öğretmen adaylarının öz-yeterlik inançları hangi düzeydedir?

1.2 Fen bilimleri ve ilköğretim matematik öğretmen adaylarının öz-yeterlik kaynakları hangi düzeydedir?

2. Fen bilimleri ve ilköğretim matematik öğretmen adaylarının öz-yeterlik inançları ve öz-yeterlik kaynakları öğrenim gördükleri program türü, sınıf düzeyi ve cinsiyete göre farklılık göstermekte midir?

2.1. Fen bilimleri ve ilköğretim matematik öğretmen adaylarının öz-yeterlik inançları öğrenim gördükleri program türüne göre farklılık göstermekte midir?

2.2. Fen bilimleri ve ilköğretim matematik öğretmen adaylarının öz-yeterlik inançları sinıf düzeyine göre farklılık göstermekte midir?

2.3. Fen bilimleri ve ilköğretim matematik öğretmen adaylarının öz-yeterlik inançları cinsiyete göre farklılık göstermekte midir?

2.4. Fen bilimleri ve ilköğretim matematik öğretmen adaylarının öz-yeterlik kaynakları öğrenim gördükleri program türüne göre farklılık göstermekte midir?

2.5. Fen bilimleri ve ilköğretim matematik öğretmen adaylarının öz-yeterlik kaynakları sınıf düzeyine göre farklılık göstermekte midir?

2.6. Fen bilimleri ve ilköğretim matematik öğretmen adaylarının öz-yeterlik kaynakları cinsiyete göre farklılık göstermekte midir? 


\section{Yöntem}

Araştırma kapsamında, deneysel olmayan nicel araştırma desenlerinden tarama yöntemi (Fraenkel, Wallen ve Hyun, 2011) kullanılmıştır. Bu kapsamda, katılımcıların öz-yeterlik inançları ve öz-yeterlik kaynakları öğrenim gördükleri program türü, sınıf düzeyi ve cinsiyet değişkenleri açısından incelenmiştir.

\section{Katılımcilar}

$\mathrm{Bu}$ araştırmanın evrenini, Türkiye'de devlet üniversitelerinin eğitim fakültelerinde öğrenim gören Fen Bilgisi Öğretmenliği (FBÖ) ve İlköğretim Matematik Öğretmenliği (İMÖ) programlarındaki öğretmen adayları oluşturmaktadır. Araştırmanın örneklemi, uygun örnekleme yöntemi ile belirlenmiştir (Fraenkel, Wallen ve Hyun, 2011). Buna göre; Türkiye'nin farklı coğrafi bölgelerinde bulunan beş devlet üniversitesinin eğitim fakültelerinde FBÖ ve İMÖ programlarında öğrenim gören öğretmen adayları ile çalışma gerçekleştirilmiştir. Beş devlet üniversitesinden toplam 885 öğretmen adayı araştırmaya katılmıştır. Tablo 1 ve Tablo 2'de üniversitelere göre katılımcıların öğrenim gördükleri program türü, sınıf düzeyi ve cinsiyete göre dağılımı verilmektedir. 56 öğretmen adayı cinsiyetini bildirmediğinden iki tabloda belirtilen katılımcı sayılarında farklılık bulunmaktadır.

Tablo 1. Katılımcıların öğrenim gördükleri program türü ve sınıf düzeyine göre dağılımı

\begin{tabular}{|c|c|c|c|c|}
\hline Üniversite & Program & 3. sinıf & 4. $\sin I f$ & Toplam \\
\hline \multirow[t]{3}{*}{ A } & FBÖ & 41 & 19 & 60 \\
\hline & İMÖ & 34 & 42 & 76 \\
\hline & Toplam & 75 & 61 & 136 \\
\hline \multirow[t]{3}{*}{ B } & FBÖ & 40 & 35 & 75 \\
\hline & İMÖ & 53 & 45 & 98 \\
\hline & Toplam & 93 & 80 & 173 \\
\hline \multirow[t]{3}{*}{$\mathrm{C}$} & FBÖ & 62 & 54 & 116 \\
\hline & İMÖ & 52 & 39 & 91 \\
\hline & Toplam & 114 & 93 & 207 \\
\hline \multirow[t]{3}{*}{ D } & FBÖ & 50 & 44 & 94 \\
\hline & İMÖ & 51 & 39 & 90 \\
\hline & Toplam & 101 & 83 & 184 \\
\hline \multirow[t]{3}{*}{$\mathbf{E}$} & FBÖ & 54 & 46 & 100 \\
\hline & İMÖ & 43 & 42 & 85 \\
\hline & Toplam & 97 & 88 & 185 \\
\hline \multirow[t]{3}{*}{ Toplam } & FBÖ & 247 & 198 & 445 \\
\hline & İMÖ & 233 & 207 & 440 \\
\hline & Toplam & 480 & 405 & 885 \\
\hline
\end{tabular}

Tablo 2. Katılımcıların öğrenim gördükleri program türü ve cinsiyete göre dağılımı

\begin{tabular}{llccc}
\hline Üniversite & Program & Kadın & Erkek & Toplam \\
\hline A & FBÖ & 35 & 18 & 53 \\
\cline { 2 - 5 } & İMÖ & 48 & 23 & 71 \\
\cline { 2 - 5 } & Toplam & 83 & 41 & 123 \\
\hline B & FBÖ & 56 & 10 & 66 \\
\cline { 2 - 5 } & $\dot{\text { İMÖ }}$ & 76 & 15 & 91 \\
\cline { 2 - 5 } & Toplam & 132 & 25 & 157 \\
\hline $\mathbf{C}$ & FBÖ & 99 & 13 & 112 \\
\cline { 2 - 5 } & $\dot{\text { İMÖ }}$ & 70 & 15 & 85 \\
\cline { 2 - 5 } & Toplam & 169 & 28 & 197 \\
\hline
\end{tabular}




\begin{tabular}{llccc}
\hline Üniversite & Program & Kadın & Erkek & Toplam \\
\hline D & FBÖ & 75 & 14 & 89 \\
\cline { 2 - 5 } & İMÖ & 65 & 19 & 84 \\
\cline { 2 - 5 } & Toplam & 140 & 33 & 173 \\
\hline \multirow{2}{*}{ E } & FBÖ & 81 & 16 & 97 \\
\cline { 2 - 5 } & İMÖ & 61 & 20 & 81 \\
\cline { 2 - 5 } & Toplam & 142 & 36 & 178 \\
\hline \multirow{2}{*}{ Toplam } & FBÖ & 346 & 71 & 417 \\
\cline { 2 - 5 } & İMÖ & 320 & 92 & 412 \\
\cline { 2 - 5 } & Toplam & 666 & 163 & 829 \\
\hline
\end{tabular}

\section{Veri Toplama Araçları}

Öğretmen öz-yeterlik ölçeği. Katılımcıların öğretmen öz-yeterlik inançlarını belirlemek amacıyla Tschannen-Moran ve Woolfolk Hoy (2001) tarafından geliştirilen ve Çapa, Çakıroğlu ve Sarıkaya (2005) tarafindan Türkçe'ye uyarlanan Öğretmen Öz-Yeterlik Ölçeği kullanılmıştır. Ölçek, 24 maddeden ve üç alt boyuttan oluşmaktadır (Tablo 3). Maddeler 9'lu Likert formatında olup yetersiz (1), çok az yeterli (3), biraz yeterli (5), oldukça yeterli (7) ve çok yeterli (9) şeklinde derecelendirilmiştir.

Ölçeğin mevcut araştırma örneklemindeki geçerliğini test etmek amacıyla Doğrulayıcı Faktör Analizi (DFA) yapılmıştır. Analiz sonucunda elde edilen değerler: $\chi^{2} / d f(931.57 / 249)=$ 3.74, RMSEA $=.056(90 \% \mathrm{CI}=.052, .060), S R M R=.052, \mathrm{GFI}=.87, C F I=.99$ ve $N N F I=.98$ incelendiğinde analiz yapılan bu veri setinin önerilen model ile iyi uyum gösterdiği sonucuna ulaşılmıştır (Browne ve Cudeck, 1993; Jöreskog ve Sörbom, 1993; Kline, 2005). Tüm maddeler dahil edildiğinde ölçeğin Cronbach's alpha değeri .94'dir. Ölçeğin alt boyutlara göre özellikleri ise Tablo 3 'te sunulmaktadır.

Tablo 3. Öğretmen öz-yeterlik ölçeğinin özellikleri

\begin{tabular}{lcc}
\hline Alt Boyut & Cronbach's Alpha Değeri & Madde Sayısı \\
\hline Öğrenci Katılımı & .84 & 8 \\
\hline Öğretim Stratejileri & .86 & 8 \\
\hline Sınıf Yönetimi & .88 & 8 \\
\hline
\end{tabular}

Öğretmen adaylarının öz-yeterlik puanları, her bir alt boyut için, o boyuta ait maddelerin aritmetik ortalaması hesaplanarak bulunmuştur. Öz-yeterlik düzeyleri hesaplanırken ölçekten alınabilecek en yüksek puan ile en düşük puan farkı beşe bölünmüştür (düzey= $(9-1) / 5=1.60$ ). Bulunan 1.60 değeri, olası en düşük değere (1.00) eklenerek sınır değerler ve değerlendirme kriterleri belirlenmiştir (1.00-2.60= yetersiz, 2.61-4.20= çok az yeterli, 4.21-5.80= biraz yeterli, 5.81-7.40= oldukça yeterli, 7.41-9.00= çok yeterli).

Öz-yeterlik kaynakları ölçeği. Katılımcıların öz-yeterlik kaynaklarını belirlemek amacıyla Kieffer ve Henson (2000) tarafından geliştirilen ve Çapa-Aydın, UzuntiryakiKondakçı, Temli ve Tarkın (2013) tarafindan Türkçe'ye uyarlanan Öz-Yeterlik Kaynakları Ölçeği kullanılmıştır. Uyarlanan ölçek dört alt boyuttan ve 27 maddeden oluşmaktadır (Tablo 4). Maddeler 7'li Likert formatında olup kesinlikle doğru değil (1), genellikle doğru değil (2), bazen doğru (3), ara sıra doğru (4), çoğunlukla doğru (5), genellikle doğru (6) ve her zaman doğru (7) şeklinde derecelendirilmiştir.

Ölçeğin mevcut araştırmanın örneklemdeki geçerliğini test etmek amacıyla DFA yapılmıştır. Analiz sonucunda elde edilen değerler: $\chi^{2} / d f(1594.83 / 314)=5.08, R M S E A=.068$ $(90 \% \mathrm{CI}=.065, .071), S R M R=.085, G F I=.82, C F I=.95$ ve $N N F I=.95$ incelendiğinde analiz yapılan veri setinin önerilen modelle orta derecede uyum gösterdiği sonucuna ulaşılmıştır. Tüm 
maddeler dahil edildiğinde ölçeğin Cronbach's alpha değeri .86’dir. Alt boyutlara göre ölçeğin özellikleri ise Tablo 4'te sunulmaktadır.

Tablo 4. Öz-yeterlik kaynakları ölçeğinin özellikleri

\begin{tabular}{lcc}
\hline Alt Boyut & Cronbach's Alpha Değeri & Madde Sayısı \\
\hline Doğrudan Yaşantılar & .76 & 8 \\
\hline Dolaylı Yaşantılar & .76 & 7 \\
\hline Sözel İkna & .75 & 5 \\
\hline Fizyolojik ve Duygusal Durum & .80 & 7 \\
\hline
\end{tabular}

Öğretmen adaylarının öz-yeterlik kaynakları için puanlar hesaplanırken her bir alt boyut için, o boyuta ait maddelerin aritmetik ortalaması alınmıştır. Öz-yeterlik inançlarının düzeyi, ölçekten alınabilecek en yüksek ile en düşük puan farkı yediye bölünerek hesaplanmıştır (düzey $=(7-1) / 7=0.86)$. Olasi en düşük değere (1.00) hesaplanan 0.86 değeri eklenerek sinır değerler ve düzeyler belirlenmiştir (1.00-1.86= Kesinlikle Doğru Değil, 1.87-2.72= Genellikle Doğru Değil, 2.73-3.58= Bazen Doğru, 3.59-4.44= Ara Stra Doğru, 4.45-5.30= Çoğunlukla Doğru, 5.31-6.16= Genellikle Doğru, 6.17-7.00= Her Zaman Doğru).

\section{Verilerin Toplanması}

Veri toplama araçları, 2018-2019 akademik yılı bahar döneminde uygun olan ders saatlerinde araştırmacılar tarafından uygulanmıştır. Öğretmen adaylarına çalışma hakkında bilgi verilmiş ve verdikleri bilgilerin sadece araştırma için kullanılacağı, ders notlarını etkilemeyeceği veya kişisel herhangi bir bilgi istenmeyeceği söylenmiştir. Öğretmen adaylarına ölçekler aynı anda dağıtılmış ve tamamlamaları ortalama 20 dakika sürmüştür. Verilerin toplanması sürecinde, öğretmen adaylarının isimleri veya onların kimliğini ortaya çıkaracak herhangi bir bilgi istenmemiştir.

\section{Verilerin Analizi}

$\mathrm{Bu}$ araştırma kapsamında toplam 885 öğretmen adayından veri toplanmıştır. Veri analizi öncesinde, veri temizleme işlemi gerçekleştirilmiştir. İlk olarak, kayıp verilerin rastgele olup olmadığ1 ve oranı kontrol edilmiştir. Little's MCAR test sonucuna $(\mathrm{p}>.05)$ göre kayıp değerlerin rastgele olduğu ve kayıp veri oranının $\% 5$ 'in altında kaldığ 1 gözlenmiştir. Bunun sonucunda kayıp verilerle baş etmede madde ortalaması atama yöntemi güvenle uygulanmıştır (Tabachnick ve Fidell, 2007).

Katılımcıların öz-yeterlik inançları ve öz-yeterlik kaynaklarının düzeyleri, program türü, sınıf düzeyi ve cinsiyet değişkenlerine göre betimsel istatistikler kullanılarak belirlenmiştir. Katılımcıların öz-yeterlik inançları ve öz-yeterlik kaynaklarında belirtilen değişkenlere göre fark olup olmadığı MANOVA kullanılarak test edilmiştir. Analiz öncesi her bir test ile ilgili varsayımlar (çok değişkenli uç değer, örneklem büyüklüğü, normallik, doğrusallık, bağımlı değişkenler arası korelasyonlar, varyansların eşitliği, varyans-kovaryans matris eşitliği) kontrol edilmiştir. İlk olarak çok değişkenli uç-değer varsayımı test edilirken Mahalanobis uzaklığ kontrol edilmiştir. Üç alt boyuta sahip öz-yeterlik inancı değişkeni için 16.27 kritik değerini (Pallant, 2010) aşan yedi katılımc1 ve dört alt boyuta sahip öz-yeterlik kaynakları değişkeni için 18.47 kritik değerini (Pallant, 2010) aşan on iki katılımcı analizlere dâhil edilmemiştir. Bunun sonucunda öz-yeterlik inancı ile ilgili MANOVA analizlerinde 878, öz-yeterlik kaynakları ile ilgili MANOVA analizlerinde 873 katılımcı yer almaktadır. Analizlerde yer alan katılımcısı sayısı örneklem büyüklüğü varsayımını rahatlıkla karşılamaktadır. Ardından, ortalama, basıklık-çarpıklık katsayıları, Kolmogorov-Smirnov normallik testi ve Q-Q grafikleri incelenerek tüm değişkenler için verilerin normal dağ 11 im gösterdiği saptanmıştır. Ayrıca Mardia's test sonuçlarına $(p>05)$ göre çok değişkenli normallik varsayımı da sağlanmaktadır. Doğrusallık için ikili değişkenler için saçılma diyagramları incelenmiştir. Şekiller doğrusal olmayan bir örüntü göstermediğinden, tüm 
ilişkilerin doğrusal olduğu varsayılmıştır. Son olarak, ikili korelasyonlar kontrol edildiğinde .80'nın altında kaldığı (Tabachnick ve Fidell, 2007) için bağımlı değişkenler arası korelasyonlar varsayımı karşılanmıştır. Varyansların eşitliği ve varyans-kovaryans matris eşitliği varsayımları ise "Bulgular" kısmında ilgili testlerden önce açıklanmıştır. Hipotez testi aşamasında çok değişkenli F-testinin değerlendirilmesinde varyans-kovaryans matrislerinin eşitliği varsayımı sağlandığı analizler için Wilks' Lambda, sağlanamadığı analizler için Pillai's Trace değeri dikkate alınmıştır (Tabachnick ve Fidell, 2007). Ayrıca, bağımlı değişkenlerdeki varyansın ne kadarının bağımsız değişken tarafından açıklandığını belirlemek için kısmi eta-kare değerine $\left(\eta^{2}\right)$ bakılmıştır. Kısmi eta-kare değeri $\eta^{2}=.01$ küçük, $\eta^{2}=.06$ orta ve $\eta^{2}=.14$ büyük düzeyde bir etki olarak değerlendirilmiştir (Cohen, 1988).

\section{Bulgular}

\section{Öz-Yeterlik İnançları ve Öz-Yeterlik Kaynaklarının Düzeyine İlişkin Bulgular}

Katılımcıların öz-yeterlik inançları ve öz-yeterlik kaynaklarının düzeyini belirlemek için hesaplanan betimsel istatistikler daha önce Veri Toplama Araçları başlığı altında açıklanan sınır değerler ile karşılaştırılarak karar verilmiştir.

Öz-yeterlik inançlarının düzeyine ilişkin bulgular. Katılımcıların öz-yeterlik inançlarının düzeyini belirlemek amacıyla Öğretmen Öz-Yeterlik Ölçeği’nin her bir alt boyutu için öğrenim gördükleri program türü, sınıf düzeyi ve cinsiyet değişkenlerine göre ve katılımcıların tamamı için hesaplanan betimsel istatistik sonuçları Tablo 5 'te sunulmaktadır.

Tablo 5. Katılımcıların öz-yeterlik inançlarına ilişkin betimsel istatistik sonuçları

\begin{tabular}{|c|c|c|c|c|c|c|c|c|}
\hline Alt Boyut & Değişken & & $\mathbf{N}$ & $\begin{array}{c}\text { En Düşük } \\
\text { Değer }\end{array}$ & $\begin{array}{c}\text { En Yüksek } \\
\text { Değer }\end{array}$ & $\overline{\mathbf{X}}$ & SS & Düzey \\
\hline \multirow{8}{*}{$\begin{array}{l}\text { Öğrenci } \\
\text { Katılımı }\end{array}$} & \multirow{2}{*}{ Program } & FBÖ & 445 & 3.63 & 9.00 & 6.84 & .88 & $\begin{array}{c}\text { Oldukça } \\
\text { Yeterli }\end{array}$ \\
\hline & & İMÖ & 433 & 3.88 & 9.00 & 6.47 & .90 & $\begin{array}{c}\text { Oldukça } \\
\text { Yeterli }\end{array}$ \\
\hline & \multirow{2}{*}{ Sinif } & 3.sinif & 477 & 3.63 & 9.00 & 6.61 & .91 & $\begin{array}{c}\text { Oldukça } \\
\text { Yeterli }\end{array}$ \\
\hline & & 4.sinif & 401 & 4.25 & 9.00 & 6.71 & .91 & $\begin{array}{c}\text { Oldukça } \\
\text { Yeterli } \\
\end{array}$ \\
\hline & \multirow{4}{*}{ Cinsiyet } & Kadın & 659 & 3.63 & 9.00 & 6.64 & .90 & $\begin{array}{c}\text { Oldukça } \\
\text { Yeterli }\end{array}$ \\
\hline & & Erkek & 163 & 4.13 & 8.88 & 6.74 & .93 & $\begin{array}{c}\text { Oldukça } \\
\text { Yeterli }\end{array}$ \\
\hline & & $\begin{array}{l}\text { Kayip } \\
\text { Veri }\end{array}$ & 56 & 4.25 & 8.50 & 6.53 & .97 & $\begin{array}{c}\text { Oldukça } \\
\text { Yeterli }\end{array}$ \\
\hline & & Toplam & 878 & 3.63 & 9.00 & 6.66 & .91 & $\begin{array}{c}\text { Oldukça } \\
\text { Yeterli }\end{array}$ \\
\hline \multirow{6}{*}{$\begin{array}{l}\text { Öğretim } \\
\text { Stratejileri }\end{array}$} & \multirow{2}{*}{ Program } & FBÖ & 445 & 3.13 & 9.00 & 6.83 & .92 & $\begin{array}{c}\text { Oldukça } \\
\text { Yeterli }\end{array}$ \\
\hline & & İMÖ & 433 & 3.63 & 9.00 & 6.62 & .96 & $\begin{array}{c}\text { Oldukça } \\
\text { Yeterli }\end{array}$ \\
\hline & \multirow{2}{*}{ Sinif } & 3.sinıf & 477 & 3.13 & 9.00 & 6.63 & .94 & $\begin{array}{c}\text { Oldukça } \\
\text { Yeterli }\end{array}$ \\
\hline & & 4.sinif & 401 & 3.63 & 9.00 & 6.84 & .95 & $\begin{array}{c}\text { Oldukça } \\
\text { Yeterli } \\
\end{array}$ \\
\hline & \multirow{2}{*}{ Cinsiyet } & Kadın & 659 & 3.13 & 9.00 & 6.72 & .93 & $\begin{array}{c}\text { Oldukça } \\
\text { Yeterli }\end{array}$ \\
\hline & & Erkek & 163 & 4.50 & 9.00 & 6.83 & .97 & $\begin{array}{c}\text { Oldukça } \\
\text { Yeterli }\end{array}$ \\
\hline
\end{tabular}




\begin{tabular}{|c|c|c|c|c|c|c|c|c|}
\hline Alt Boyut & Değişken & & $\mathbf{N}$ & $\begin{array}{c}\text { En Düşük } \\
\text { Değer }\end{array}$ & $\begin{array}{l}\text { En Yüksek } \\
\text { Değer }\end{array}$ & $\overline{\mathbf{X}}$ & SS & Düzey \\
\hline & & $\begin{array}{l}\text { Kayıp } \\
\text { Veri }\end{array}$ & 56 & 3.63 & 8.88 & 6.48 & 1.06 & $\begin{array}{c}\text { Oldukça } \\
\text { Yeterli }\end{array}$ \\
\hline & & Toplam & 878 & 3.13 & 9.00 & 6.73 & .95 & $\begin{array}{c}\text { Oldukça } \\
\text { Yeterli }\end{array}$ \\
\hline \multirow{8}{*}{$\begin{array}{l}\text { Sınıf } \\
\text { Yönetimi }\end{array}$} & \multirow{2}{*}{ Program } & FBÖ & 445 & 3.67 & 9.00 & 6.86 & .96 & $\begin{array}{c}\text { Oldukça } \\
\text { Yeterli }\end{array}$ \\
\hline & & İMÖ & 433 & 3.25 & 9.00 & 6.59 & 1.03 & $\begin{array}{c}\text { Oldukça } \\
\text { Yeterli }\end{array}$ \\
\hline & \multirow{2}{*}{ Sinif } & 3.sinif & 477 & 3.25 & 9.00 & 6.68 & 1.02 & $\begin{array}{c}\text { Oldukça } \\
\text { Yeterli }\end{array}$ \\
\hline & & 4.sinif & 401 & 4.00 & 9.00 & 6.79 & .98 & $\begin{array}{c}\text { Oldukça } \\
\text { Yeterli }\end{array}$ \\
\hline & \multirow{4}{*}{ Cinsiyet } & Kadın & 659 & 3.25 & 9.00 & 6.68 & .97 & $\begin{array}{c}\text { Oldukça } \\
\text { Yeterli }\end{array}$ \\
\hline & & Erkek & 163 & 3.63 & 9.00 & 6.96 & 1.07 & $\begin{array}{c}\text { Oldukça } \\
\text { Yeterli }\end{array}$ \\
\hline & & $\begin{array}{l}\text { Kayıp } \\
\text { Veri }\end{array}$ & 56 & 4.00 & 8.75 & 6.69 & 1.13 & $\begin{array}{c}\text { Oldukça } \\
\text { Yeterli }\end{array}$ \\
\hline & & Toplam & 878 & 3.25 & 9.00 & 6.73 & 1.00 & $\begin{array}{c}\text { Oldukça } \\
\text { Yeterli }\end{array}$ \\
\hline
\end{tabular}

Tablo 5'teki betimsel istatistikler katılımcıların öğrenim gördükleri program türüne göre incelendiğinde katılımcıların ortalamaları öz-yeterlik inancı değişkeninin tüm alt boyutlarında birbirine oldukça yakın olmakla birlikte fen bilimleri öğretmen adaylarının ortalamalarının bir miktar yüksek olduğu gözlenmiştir. Her iki program türünde bütün alt boyutlarda hesaplanan aritmetik ortalamalar 5.81-7.40 puan aralığına denk geldiğinden oldukça yeterli düzeyde olduğu bulunmuştur. Diğer taraftan sınıf düzeyi için ölçeğin her üç alt boyutunda 4. sınıf öğretmen adaylarının daha yüksek ortalamaya sahip oldukları görülmüştür. Benzer şekilde her iki sınıf düzeyinde bütün alt boyutlarda aritmetik ortalama değerleri oldukça yeterli düzeyde bulunmuştur. Son olarak cinsiyet için aritmetik ortalamalar incelendiğinde, erkeklerin öz-yeterlik inançlarının kadınlara göre bir miktar daha yüksek olduğu görülmüştür. Aynı şekilde cinsiyete göre de bütün alt boyutlarda aritmetik ortalama değerleri oldukça yeterli düzeyde çıkmıştır. Son olarak, katılımcıların tamamı için aritmetik ortalama değerleri incelendiğinde her üç alt boyut için oldukça yeterli düzey olarak kabul edilen 5.81-7.40 puan aralığında değerler elde edilmiştir. Özetle, öz-yeterlik inançları değişkeninin tüm alt boyutları için aritmetik ortalama değerleri hem incelenen program türü, sınıf düzeyi ve cinsiyete göre hem de grubun tamamı için oldukça yeterli düzeyde bulunmuştur.

Öz-yeterlik kaynaklarının düzeyine ilişkin bulgular. Katılımcıların öz-yeterlik kaynaklarının düzeyini belirlemek amacıyla Öz-Yeterlik Kaynakları Ölçeği'nin her bir alt boyutu için öğrenim gördükleri program türü, sınıf düzeyi ve cinsiyet değişkenlerine göre ve katılımcıların tamamı için elde edilen bulgular Tablo 6'da sunulmaktadır.

Tablo 6. Katılımcıların öz-yeterlik kaynaklarına ilişkin betimsel istatistik sonuçları

\begin{tabular}{|c|c|c|c|c|c|c|c|c|}
\hline Alt Boyut & & Program & $\mathbf{N}$ & $\begin{array}{c}\text { En Düşük } \\
\text { Değer }\end{array}$ & $\begin{array}{c}\text { En Yüksek } \\
\text { Değer }\end{array}$ & $\overline{\mathbf{X}}$ & SS & Düzey \\
\hline \multirow{2}{*}{$\begin{array}{l}\text { Doğrudan } \\
\text { Yaşantılar }\end{array}$} & \multirow{2}{*}{ Program } & FBÖ & 438 & 1.88 & 7.00 & 5.29 & .87 & $\begin{array}{c}\text { Çoğunlukla } \\
\text { doğru }\end{array}$ \\
\hline & & İMÖ & 435 & 1.75 & 7.00 & 5.07 & .81 & $\begin{array}{c}\text { Çoğunlukla } \\
\text { doğru }\end{array}$ \\
\hline
\end{tabular}




\begin{tabular}{|c|c|c|c|c|c|c|c|c|}
\hline Alt Boyut & & Program & $\mathbf{N}$ & $\begin{array}{l}\text { En Düşük } \\
\text { Değer }\end{array}$ & $\begin{array}{c}\text { En Yüksek } \\
\text { Değer }\end{array}$ & $\overline{\mathbf{X}}$ & SS & Düzey \\
\hline & \multirow{2}{*}{ Sinif } & $3 . \sin 1 f$ & 472 & 1.75 & 6.88 & 5.00 & .87 & $\begin{array}{c}\text { Çoğunlukla } \\
\text { doğru }\end{array}$ \\
\hline & & 4.sinif & 401 & 3.00 & 7.00 & 5.40 & .76 & $\begin{array}{c}\text { Genellikle } \\
\text { doğru }\end{array}$ \\
\hline & \multirow{4}{*}{ Cinsiyet } & Kadın & 657 & 1.75 & 7.00 & 5.18 & .85 & $\begin{array}{c}\text { Çoğunlukla } \\
\text { doğru }\end{array}$ \\
\hline & & Erkek & 161 & 2.88 & 7.00 & 5.21 & .78 & $\begin{array}{c}\text { Çoğunlukla } \\
\text { doğru }\end{array}$ \\
\hline & & $\begin{array}{l}\text { Kayıp } \\
\text { Veri }\end{array}$ & 55 & 2.13 & 6.63 & 5.06 & .96 & $\begin{array}{c}\text { Çoğunlukla } \\
\text { doğru }\end{array}$ \\
\hline & & Toplam & 873 & 1.75 & 7.00 & 5.18 & .85 & $\begin{array}{l}\text { Çoğunlukla } \\
\text { doğru }\end{array}$ \\
\hline \multirow{8}{*}{$\begin{array}{l}\text { Dolaylı } \\
\text { Yaşantılar }\end{array}$} & \multirow[t]{2}{*}{ Program } & FBÖ & 438 & 2.71 & 7.00 & 5.58 & .86 & $\begin{array}{c}\text { Genellikle } \\
\text { doğru }\end{array}$ \\
\hline & & İMÖ & 435 & 2.57 & 7.00 & 5.28 & .85 & $\begin{array}{c}\text { Çoğunlukla } \\
\text { doğru }\end{array}$ \\
\hline & \multirow{2}{*}{ Sinif } & 3.sinif & 472 & 2.57 & 7.00 & 5.25 & .91 & $\begin{array}{c}\text { Çoğunlukla } \\
\text { doğru }\end{array}$ \\
\hline & & 4.sinif & 401 & 2.71 & 7.00 & 5.64 & .76 & $\begin{array}{c}\text { Genellikle } \\
\text { doğru }\end{array}$ \\
\hline & \multirow{4}{*}{ Cinsiyet } & Kadın & 657 & 2.57 & 7.00 & 5.44 & .88 & $\begin{array}{c}\text { Genellikle } \\
\text { doğru }\end{array}$ \\
\hline & & Erkek & 161 & 3.14 & 7.00 & 5.45 & .78 & $\begin{array}{c}\text { Genellikle } \\
\text { doğru }\end{array}$ \\
\hline & & $\begin{array}{l}\text { Kayip } \\
\text { Veri }\end{array}$ & 55 & 2.71 & 6.86 & 5.16 & .92 & $\begin{array}{l}\text { Çoğunlukla } \\
\text { doğru }\end{array}$ \\
\hline & & Toplam & 873 & 2.57 & 7.00 & 5.43 & .87 & $\begin{array}{c}\text { Genellikle } \\
\text { doğru }\end{array}$ \\
\hline \multirow{8}{*}{ Sözel İkna } & \multirow{2}{*}{ Program } & FBÖ & 438 & 2.20 & 7.00 & 5.70 & .90 & $\begin{array}{c}\text { Genellikle } \\
\text { doğru }\end{array}$ \\
\hline & & İMÖ & 435 & 2.20 & 7.00 & 5.42 & .88 & $\begin{array}{c}\text { Genellikle } \\
\text { doğru }\end{array}$ \\
\hline & \multirow{2}{*}{ Sinif } & 3.sinif & 472 & 2.20 & 7.00 & 5.53 & .92 & $\begin{array}{c}\text { Genellikle } \\
\text { doğru }\end{array}$ \\
\hline & & 4.sinif & 401 & 2.80 & 7.00 & 5.60 & .87 & $\begin{array}{c}\text { Genellikle } \\
\text { doğru }\end{array}$ \\
\hline & \multirow{4}{*}{ Cinsiyet } & Kadın & 657 & 2.20 & 7.00 & 5.58 & .90 & $\begin{array}{c}\text { Genellikle } \\
\text { doğru }\end{array}$ \\
\hline & & Erkek & 161 & 2.80 & 7.00 & 5.51 & .91 & $\begin{array}{c}\text { Genellikle } \\
\text { doğru }\end{array}$ \\
\hline & & $\begin{array}{l}\text { Kayıp } \\
\text { Veri }\end{array}$ & 55 & 3.20 & 7.00 & 5.48 & .85 & $\begin{array}{c}\text { Genellikle } \\
\text { doğru }\end{array}$ \\
\hline & & Toplam & 873 & 2.20 & 7.00 & 5.56 & .90 & $\begin{array}{c}\text { Genellikle } \\
\text { doğru }\end{array}$ \\
\hline \multirow{3}{*}{$\begin{array}{l}\text { Fizyolojik } \\
\text { ve } \\
\text { Duygusal } \\
\text { Durumlar }\end{array}$} & \multirow{2}{*}{ Program } & FBÖ & 438 & 1.00 & 7.00 & 4.57 & 1.19 & $\begin{array}{c}\text { Çoğunlukla } \\
\text { doğru }\end{array}$ \\
\hline & & İMÖ & 435 & 1.00 & 6.71 & 4.41 & 1.08 & $\begin{array}{c}\text { Ara sıra } \\
\text { doğru }\end{array}$ \\
\hline & Sinif & 3.sinif & 472 & 1.00 & 7.00 & 4.46 & 1.11 & $\begin{array}{l}\text { Çoğunlukla } \\
\text { doğru }\end{array}$ \\
\hline
\end{tabular}




\begin{tabular}{|c|c|c|c|c|c|c|c|c|}
\hline Alt Boyut & & Program & $\mathbf{N}$ & $\begin{array}{l}\text { En Düssük } \\
\text { Değer }\end{array}$ & $\begin{array}{c}\text { En Yüksek } \\
\text { Değer }\end{array}$ & $\overline{\mathbf{X}}$ & SS & Düzey \\
\hline & & 4.sinif & 401 & 1.00 & 7.00 & 4.53 & 1.17 & $\begin{array}{c}\text { Çoğunlukla } \\
\text { doğru }\end{array}$ \\
\hline & \multirow{4}{*}{ Cinsiyet } & Kadın & 657 & 1.00 & 7.00 & 4.54 & 1.11 & $\begin{array}{c}\text { Çoğunlukla } \\
\text { doğru }\end{array}$ \\
\hline & & Erkek & 161 & 1.00 & 7.00 & 4.31 & 1.24 & $\begin{array}{c}\text { Ara sira } \\
\text { doğru }\end{array}$ \\
\hline & & $\begin{array}{l}\text { Kayıp } \\
\text { Veri } \\
\end{array}$ & 55 & 1.00 & 6.86 & 4.38 & 1.14 & $\begin{array}{c}\text { Ara sira } \\
\text { doğru }\end{array}$ \\
\hline & & Toplam & 873 & 1.00 & 7.00 & 4.49 & 1.14 & $\begin{array}{c}\text { Çoğunlukla } \\
\text { doğru }\end{array}$ \\
\hline
\end{tabular}

Tablo 6'daki betimsel istatistik sonuçları, katılımcıların öğrenim gördükleri program türüne göre incelendiğinde her iki programda doğrudan yaşantılar boyutu için aritmetik ortalamalar 4.44-5.30 puan aralığına denk geldiğinden çoğunlukla doğru düzeyde oldukları gözlenmiştir. Dolaylı yaşantılar boyutu için fen bilimleri öğretmen adaylarının aritmetik ortalaması 5.30-6.16 puan aralığına denk geldiğinden genellikle doğru, ilköğretim matematik öğretmen adaylarının ise 4.44-5.30 puan aralığına denk geldiğinden çoğunlukla doğru düzeyde bulunmuştur. Sözel ikna boyutu için aritmetik ortalamalar her iki program türünde 5.30-6.16 puan aralığına denk geldiğinden genellikle doğru düzeyde bulunmuştur. Fizyolojik ve duygusal durumlar boyutunda ise fen bilimleri öğretmen adaylarının aritmetik ortalaması çoğunlukla doğru düzeyde, ilköğretim matematik öğretmen adaylarının aritmetik ortalaması ise ara sira doğru düzeyde oldukları bulunmuştur. Sınıf düzeyine göre bakıldığında tüm alt boyutlarda 4 . sınıfların aritmetik ortalaması daha yüksek bulunmuştur. Doğrudan yaşantılar ve dolaylı yaşantılar alt boyutları için üçüncü sınıfta öğrenim gören öğretmen adaylarının çoğunlukla doğru düzeyde iken dördüncü sınıfta öğrenim gören öğretmen adaylarının genellikle doğru düzeyde olduğu görülmüştür. Sözel ikna alt boyutu için her iki sınıfta öğrenim gören öğretmen adayları genellikle doğru düzeyde iken fizyolojik ve duygusal durumlar için her iki grup da çoğunlukla doğru düzeydedir. Diğer taraftan cinsiyete göre bakıldığında her iki cinsiyet grubunun doğrudan yaşantılar alt boyutunda çoğunlukla doğru düzeyde, dolaylı yaşantılar ve sözel ikna için genellikle doğru düzeyde olduğu görülmüştür. Fizyolojik ve duygusal durumlar alt boyutunda ise kadınlar çoğunlukla doğru düzeyde iken erkekler ara sıra doğru düzeydedir. Son olarak katılımcıların tamamı için bakıldığında öz-yeterlik kaynakları ölçeği alt boyutları olan doğrudan yaşantılar ve fizyolojik ve duygusal durumlar alt boyutları için hesaplanan aritmetik ortalamalar çoğunlukla doğru düzeyde bulunmuştur. Dolaylı yaşantılar ve sözel ikna alt boyutları için ise genellikle doğru düzeyde oldukları görülmüştür. Özetle, öz-yeterlik kaynakları değişkeni için ölçeğin alt boyutları açısından düzey farklılıkları gözlenmiştir.

Öğrenim Görülen Program Türü, Sınıf Düzeyi ve Cinsiyet Değişkenlerine Göre ÖzYeterlik İnançları ve Öz-Yeterlik Kaynaklarına İliş̧kin Bulgular

Katılımcıların öz-yeterlik inançları ve öz-yeterlik kaynaklarının öğrenim gördükleri program türü, sınıf düzeyi ve cinsiyet değişkenlerine göre farklılık gösterip göstermediğini test etmek için altı farklı tek yönlü MANOVA uygulanmıştır ve her bir analize ait bulgular ayrı bir başlık altında rapor edilmiştir.

Öğrenim görülen program türüne göre öz-yeterlik inançlarına ilişkin bulgular. Katılımcıların öz-yeterlik inançlarının alt boyutlarının doğrusal bir kombinasyonu üzerinden öğrenim gördükleri program türüne göre gruplar arasında istatistiksel olarak anlamlı farklılıkların olup olmadığını test etmek için tek yönlü MANOVA uygulanmıştır. Analiz öncesi varsayımlar kontrol edilirken Levene's Testi sonucuna göre varsansların eşitliği varsayımı sınıf yönetimi alt boyutu için $(\mathrm{p}<.05)$ sağlanamazken diğer iki alt boyut için $(\mathrm{p}>.05)$ karşılanmıştır. 
$\mathrm{Bu}$ varsayımın sağlanamaması analiz sonuçlarını ciddi bir şekilde etkilememektedir (Tabachnick ve Fidell, 2007). Box's M Testi sonucuna (Box’s M=7.195; F=1.195; p > .05) göre varyans-kovaryans matrislerinin eşitliği varsayımı sağlanmıştır.

Hipotez testi için çok değişkenli F-testi sonucuna göre öz-yeterlik inançlarının alt boyutlarının doğrusal bir kombinasyonu için gruplar arasında istatistiksel olarak anlamlı farklılık bulunmuştur [Wilks' Lambda $\left.=.950, F(3,874)=15.191, \mathrm{p}<.05, \eta^{2}=.050\right]$. Kısmi etakare değeri varyansın sadece \%5'ni açıklayarak düşük bir etki büyüklügüne işaret etmektedir. Farkın hangi boyutlarda olduğunu tespit etmek için her bir alt boyut için tek değişkenli F-testi sonuçlarına bakılmıştır (Tablo 7). Tip-I hata oranını düşürmek için Bonferroni düzeltmesi (Pallant, 2010) yapılmıştır $(\alpha=.05 / 3=.017)$.

Tablo 7. Öz-yeterlik inançları için tek değişkenli test sonuçları

\begin{tabular}{lccccc}
\hline Alt Boyut & $\boldsymbol{F}$ & $\boldsymbol{S S}$ & Hatanın s.d. & p & Kısmi $\boldsymbol{\eta}^{\mathbf{2}}$ \\
\hline Öğgrenci Katılımı & 38.006 & 1 & 876 & $.000^{*}$ & .042 \\
Öğretim Stratejisi & 10.726 & 1 & 876 & $.001^{*}$ & .012 \\
Sınıf Yönetimi & 16.508 & 1 & 876 & $.000^{*}$ & .018 \\
\hline
\end{tabular}

$* \mathrm{p}<.05$

Tablo 7 incelendiğinde her üç alt boyut için gruplar arasında anlamlı farkın bulunduğu görülmektedir. Tablo 5'teki betimsel istatistiklere bakıldığında, her üç alt boyut için fen bilimleri öğretmen adaylarının aritmetik ortalamalarının daha fazla olduğu, dolayısı ile özyeterlik inançlarının anlamlı düzeyde daha yüksek olduğu görülmüştür. Kısmi eta-kare değerleri incelendiğinde, bütün alt boyutlar için düşük etki büyüklüğü bulunmuştur.

Sınıf düzeyine göre öz-yeterlik inançlarına ilişkin bulgular. İkinci MANOVA için Levene's Testi sonucunda ( $\mathrm{p}>$.05) her üç alt boyut için varsansların eşitliği varsayımı ve Box's $\mathrm{M}$ Testi sonucunda (Box's $\mathrm{M}=2.320 ; \mathrm{F}=.385 ; \mathrm{p}>$.05) varyans-kovaryans matrislerinin eşitliğ $i$ varsayımı karşılanmıştır. Çok değişkenli F-testi sonucu öz-yeterlik inançlarının alt boyutlarının doğrusal bir kombinasyonu için sınıf düzeyi değişkeni açısından gruplar arasında istatistiksel olarak anlamlı farklılık olduğunu ortaya koymaktadır [Wilks' Lambda $=.984, F(3,874)=4.863$, $\left.\mathrm{p}<.05, \eta^{2}=.016\right]$. Kısmi eta-kare değeri varyansın \%1.6'sını açılklayarak bu analiz için etki büyüklüğünün düşük olduğunu göstermektedir. Tek değişkenli F-testi sonuçları Tablo 8'da sunulmuştur.

Tablo 8. Öz-yeterlik inançları için tek değişkenli test sonuçları

\begin{tabular}{lccccc}
\hline Alt Boyut & $\boldsymbol{F}$ & s.d. & Hatanın s.d. & $\mathbf{p}$ & Kısmi $\boldsymbol{\eta}^{\mathbf{2}}$ \\
\hline Öğrenci Katılımı & 2.540 & 1 & 876 & .111 & .003 \\
Öğretim Stratejisi & 10.892 & 1 & 876 & $.001^{*}$ & .012 \\
Sınıf Yönetimi & 2.343 & 1 & 876 & .126 & .003 \\
\hline
\end{tabular}

$* \mathrm{p}<.05$

Tablo 8 incelendiğinde Bonferroni düzeltmesi yapıldıktan sonra $(\alpha=.05 / 3=.017)$ yalnız ögretim stratejileri boyutu için gruplar arasında anlamlı farkın bulunduğu görülmüştür. Tablo 5 'teki betimsel istatistikler incelendiğinde, ögretim stratejileri boyutunda 4. sinıfların $(\bar{X}=$ 6.84), 3. sınıflara ( $\bar{X}=6.63)$ göre öz-yeterlik inançlarının anlamlı düzeyde daha yüksek olduğu görülmüştür. Kısmi eta-kare değeri düşük düzeyde bir etki büyüklüğüne işaret etmektedir.

Cinsiyete göre öz-yeterlik inançlarına ilişkin bulgular. Üçüncü MANOVA için de Levene's Testi $(\mathrm{p}>.05)$ her üç alt boyut için varsansların eşitliği varsayımını ve Box's M Testi (Box's M=11.015; F=1.823; p > .05) varyans-kovaryans matrislerinin eşitliği varsayımını sağlamaktadır. Çok değişkenli F-testi sonucuna göre öz-yeterlik inançlarının alt boyutlarının doğrusal bir kombinasyonu üzerinden cinsiyete göre gruplar arasında istatistiksel olarak anlamlı farklılık olduğunu göstermiştir [Wilks' Lambda $=.982, F(3,818)=5.068, \mathrm{p}<.05, \eta^{2}=$ 
.018]. Kısmi eta-kare değeri incelendiğinde, varyansın \%1.8'ini açıklayarak düşük bir etki büyüklügüne işaret etmektedir. Tek değişkenli F-testi sonuçları Tablo 9'de sunulmuştur.

Tablo 9. Öz-yeterlik inançları için tek değişkenli test sonuçları

\begin{tabular}{lccccc}
\hline Alt Boyut & $\boldsymbol{F}$ & s.d. & Hatanın s.d. & $\mathbf{p}$ & Kısmi $\boldsymbol{\eta}^{\mathbf{2}}$ \\
\hline Ö̆grenci Katılımı & 1.439 & 1 & 820 & .231 & .002 \\
Öğretim Stratejisi & 1.637 & 1 & 820 & .201 & .002 \\
Sınıf Yönetimi & 10.859 & 1 & 820 & $.001^{*}$ & .013 \\
\hline $\mathrm{p}<.05$ & & & & &
\end{tabular}

Tablo 9 incelendiğinde yalnızca sınıf yönetimi alt boyutu için gruplar arasında anlamlı farkın bulunduğu görülmektedir (Bonferroni düzeltmesi sonrası $\alpha=.05 / 3=.017$ ). Tablo 5 'teki betimsel istatistiklere bakıldığında, sını yönetimi alt boyutunda erkeklerin kadınlara kıyasla özyeterlik inançlarının anlamlı düzeyde daha yüksek olduğu görülmüştür. Kısmi eta-kare değeri bu etkinin düşük olduğunu göstermektedir.

Öğrenim görülen program türüne göre öz-yeterlik kaynaklarına ilişkin bulgular. Dördüncü MANOVA için Levene’s Testi sonucuna göre varsansların eşitliği varsayımı fizyolojik ve duygusal durumlar alt boyutu için $(\mathrm{p}<.05)$ sağlanamazken diğer üç alt boyut için ( $\mathrm{p}>$.05) karşılanmıştır. Bu varsayımın sağlanamaması analiz sonuçlarını ciddi bir şekilde etkilememektedir (Tabachnick ve Fidell, 2007). Box's M Testi sonucuna (Box’s M=18.504; $\mathrm{F}=1.841 ; \mathrm{p}<.05$ ) göre varyans-kovaryans matrislerinin eşitliği varsayımını sağlanamadığı için çok değişkenli F-testi için Pillai's Trace değeri dikkate alınmıştır. Çok değişkenli F-testi sonucu öz-yeterlik kaynaklarının alt boyutlarının doğrusal bir kombinasyonu için program türüne göre gruplar arasında istatistiksel olarak anlamlı bir farklılık ortaya koymaktadır [Pillai's Trace= $\left..033, F(4,868)=7.418, \mathrm{p}<.05, \eta^{2}=.033\right]$. Kısmi eta-kare değeri varyansın \%3.3'ünü açıklayarak düşük bir etki büyüklüğüne işaret etmektedir. Tek değişkenli F-testi sonuçlarına ilişkin bulgular Tablo 10 'de sunulmuştur. Bonferroni düzeltmesi $(\alpha=.05 / 4=.012)$ yapılarak Tip-I hata oranı düşürülmüştür.

Tablo 10. Öz-yeterlik kaynakları için tek değişkenli test sonuçları

\begin{tabular}{lccccc}
\hline Alt Boyut & $\boldsymbol{F}$ & s.d. & Hatanın s.d. & $\mathbf{p}$ & Kısmi $\boldsymbol{\eta}^{2}$ \\
\hline Doğrudan Yaşantılar & 14.523 & 1 & 871 &, $000^{*}$ & .016 \\
Dolaylı Yaşantılar & 26.065 & 1 & 871 &, $000^{*}$ & .029 \\
Sözel İkna & 21.109 & 1 & 871 &, $000^{*}$ & .024 \\
Fizyolojik ve & 3.986 & 1 & 871 &, 046 & .005 \\
Duygusal Durumlar & & & & &
\end{tabular}

Tablo 10 incelendiğinde fizyolojik ve duygusal durumlar alt boyutu dişında tüm alt boyutlar için gruplar arasında anlamlı farkın bulunduğu görülmektedir. Tablo 6'daki betimsel istatistiklere bakıldığında, fark bulunan her üç alt boyut için fen bilimleri öğretmen adaylarının aritmetik ortalamalarının daha fazla olduğu, dolayısı ile öz-yeterlik kaynaklarının anlamlı düzeyde daha yüksek olduğu görülmüştür. Kısmi eta-kare değerleri, fark bulunan boyutlar için etki büyüklüğünün düşük olduğunu göstermektedir.

Sınıf düzeyine göre öz-yeterlik kaynaklarına ilişkin bulgular. Beşinci MANOVA’ya ait Levene’s Testi sonucuna göre varsansların eşitliği varsayımı doğrudan yaşantılar ve dolaylı yaşantılar alt boyutları için $(\mathrm{p}<.05)$ sağlanamazken sözel ikna ve fizyolojik ve duygusal durumlar alt boyutları için $(\mathrm{p}>.05)$ karşılanmıştır. $\mathrm{Bu}$ varsayımın sağlanamaması analiz sonuçlarını ciddi bir şekilde etkilememektedir (Tabachnick ve Fidell, 2007). Box's M Testi sonucuna (Box's $M=48.117 ; \mathrm{F}=4.788 ; \mathrm{p}<.05$ ) göre varyans-kovaryans matrislerinin eşitliğ $i$ varsayımını sağlanamadığı için çok değişkenli F-testi için Pillai's Trace değeri rapor edilmiştir. 
Çok değişkenli F-testi sonucuna göre öz-yeterlik kaynaklarının alt boyutlarının doğrusal bir kombinasyonu için sınıf düzeyi açısından istatistiksel olarak anlamlı farklılık bulunmuştur [Pillai's Trace $\left.=.099, F(4,868)=23.838, \mathrm{p}<.05, \eta^{2}=.099\right]$. Kismi eta-kare değeri incelendiğinde, varyansın \%9.9'unu açıklayarak orta düzeyde bir etki büyüklüğüne işaret etmektedir. Tek değişkenli F-testi sonuçları Tablo 11'te sunulmuştur.

Tablo 11. Öz-yeterlik kaynakları için tek değișkenli test sonuçları

\begin{tabular}{lccccc}
\hline Alt Boyut & $\boldsymbol{F}$ & s.d. & Hatanın s.d. & p & Kısmi $\boldsymbol{\eta}^{\mathbf{2}}$ \\
\hline Doğrudan Yaşantılar & 51.253 & 1 & 871 & $.000 *$ & .056 \\
Dolaylı Yaşantılar & 44.382 & 1 & 871 & $.000 *$ & .048 \\
Sözel İkna & 1.438 & 1 & 871 & .231 & .002 \\
Fizyolojik ve & .826 & 1 & 871 & .364 & .001 \\
Duygusal Durumlar & & & & &
\end{tabular}

Tablo 11 incelendiğinde Bonferroni düzeltmesi yapıldıktan sonra $(\alpha=.05 / 4=.012)$ doğrudan yaşantılar ve dolayl yaşantılar alt boyutları için gruplar arasında anlamlı farkın olduğu bulunmuştur. Tablo 6'daki betimsel istatistiklere bakıldığında, fark bulunan her iki alt boyut için dördüncü sınıfların aritmetik ortalamalarının daha fazla olduğu, dolayısı ile özyeterlik kaynaklarının anlamlı düzeyde daha yüksek olduğu görülmüştür. Kısmi eta-kare değerleri, orta büyüklüğe yakın değerde etki büyüklüğüne işaret etmektedir.

Cinsiyete göre öz-yeterlik kaynaklarına ilişkin bulgular. Altıncı MANOVA için Levene's Testi sonucuna göre varsansların eşitliği varsayımı fizyolojik ve duygusal durumlar alt boyutu için $(\mathrm{p}<.05)$ sağlanamazken diğer üç alt boyut için $(\mathrm{p}>.05)$ karşılanmıştır. Bu varsayımın sağlanamaması analiz sonuçlarını ciddi bir şekilde etkilememektedir (Tabachnick ve Fidell, 2007). Box's M Testi sonucuna (Box’s $M=16.061 ; \mathrm{F}=1.591 ; \mathrm{p}>$.05) göre varyanskovaryans matrislerinin eşitliği varsayımı sağlanmaktadır. Diğerlerinden farklı olarak altıncı MANOVA için çok değişkenli F-testi sonucuna göre öz-yeterlik kaynaklarının alt boyutlarının doğrusal bir kombinasyonu için cinsiyet değişkeni açısından gruplar arasında istatistiksel olarak anlamlı bir farklılık bulunmamıştır [Wilks' Lambda $=.991, F(4,813)=1.851, \mathrm{p}>.05, \eta^{2}=.009$ ] Gruplar arasında fark bulunmadığı için tek değişkenli test sonuçları yorumlanmamıştır.

\section{Tartışma, Sonuç ve Öneriler}

$\mathrm{Bu}$ çalışmada fen bilimleri ve ilköğretim matematik öğretmen adaylarının öz-yeterlik inançları ile öz-yeterlik kaynaklarının düzeyleri belirlenmiş ve öğrenim görülen program türü, sınıf düzeyi ve cinsiyet değişkenleri açısından incelenmiştir.

Öğretmen öz-yeterlik inançlarına yönelik bulgular, ölçeğin alt boyutları açısından tüm katılımcıların kendilerini oldukça yeterli düzeyde hissettiklerini göstermiştir. En yüksek ortalama puanın sınıf yönetimi boyutunda olduğu, ardından öğretim stratejileri ve öğrenci katılımı boyutlarının geldiği saptanmıştır. Başka bir ifade ile çalışmaya katılan öğretmen adayları sınıflarını etkili bir şekilde yöneteceklerine ve sınıf ortamını iyi bir şekilde organize edeceklerine inanmaktadırlar. Öğretmen adaylarının veya öğretmenlerin öz-yeterlik inançlarını inceleyen araştırmalar da benzer şekilde öğretmen adaylarının/öğretmenlerin tüm alt boyutlarda yüksek düzeyde öğretmenlik öz-yeterlik inancına sahip olduklarını ortaya koymaktadır. Örneğin, Alrefaei (2015) fen bilimleri ve matematik öğretmenleri ile yaptığı çalışmada, iki alan için de yüksek puan sırasının sınıf yönetimi, öğretim stratejileri ve öğrenci katılımı şeklinde olduğunu rapor etmiştir. Morris-Rothschild ve Brassard (2006) öğretmenlerle yaptıkları çalışmalarında öz-yeterlik düzeyi yüksek olan öğretmenlerin farklı sınıf yönetimi tekniklerini uygulamaya meyilli olduklarını belirtmişlerdir. Şenler (2011) ise fen bilimleri öğretmen adaylarının öz-yeterlik inançlarının yüksek olduğunu belirlemiş ve en yüksek ortalama puanın 
öğretim stratejileri kullanmaya yönelik öz-yeterlik inancında olduğunu saptamıştır. Çalışmadan elde edilen bulgular, öğretmen öz-yeterlik inancı ölçeğinin üç boyutu için de fen bilimleri öğretmen adaylarının ortalamalarının, ilköğretim matematik öğretmen adaylarının ortalamalarından anlamlı derecede yüksek olduğunu göstermiştir. Bu durumun, fen bilimleri öğretmen adaylarının laboratuvar gibi uygulama alanlarında daha aktif olmalarından kaynaklandığı düşünülmektedir. Alanyazında fen bilimleri ve ilköğretim matematik öğretmen/öğretmen adaylarının öz-yeterlik inançlarının karşılaştırıldığ 1 çalışmalar sınırlı düzeydedir. Program bazında kıyaslamaları yapan Özcan (2017) çalışmasında fen bilimleri ve ilköğretim matematik öğretmen adaylarının öğretmenlik mesleğine yönelik öz-yeterlik inanç düzeyleri arasında anlamlı bir farkın olmadığını belirlemiştir. Benzer şekilde Alrefaei (2015) öğretmenlerin öz-yeterlik inançları arasında bir fark tespit etmemiştir. Azar (2010)'ın ortaöğretim düzeyinde fizik, kimya, biyoloji ve matematik öğretmenlerinin öz-yeterliklerini incelediği çalışması 150 katılımcıyla gerçekleştirilmiştir ve alanlara dayalı olarak öz-yeterlik inanç düzeyinde anlamlı fark saptanmamıştır.

Sınıf düzeyinde öz-yeterlik inançları karşılaştırıldığında 4. sınıfa devam eden öğretmen adaylarının 3. sınıfa devam edenlere kıyasla tüm alt boyutlarda daha yüksek ortalama puana sahip oldukları belirlenmiştir. Bununla birlikte, sadece öğretim stratejileri alt boyutunda anlamlı bir farkın olduğu saptanmıştır. Bu durum, alan eğitimine yönelik daha fazla ders alan, uygulama okullarında gözlem yapan ve ortaokul düzeyinde uygulamaya yönelik etkinlikleri daha çok geliştiren öğretmen adaylarının öğretim stratejilerine daha çok hâkim olduklarını ve kendilerini yeterli gördüklerini ortaya koymaktadır. Benzer şekilde, McDonnough ve Matkins (2010), öğretmenlik uygulamalarının öğretmen adaylarının öz-yeterlik inançlarına etkisini araştırdığında öğretmenlik uygulamasında deneyimi olanların öz-yeterlik inançlarının yükseldiğini ifade etmişlerdir. Aynı zamanda, Utley, Bryant ve Moseley (2005) de öğretim yöntemleri derslerini tamamlayan fen bilimleri ve matematik öğretmen adaylarının öğretim yeterliklerinin yükseldiğini belirtmişlerdir. Diğer taraftan, Özcan (2017) öğretmen adaylarının öğretmenlik mesleğine yönelik öz-yeterlik inanç düzeylerinin sınıf düzeyine göre değişmediği sonucuna ulaşmıştır. Yaman, Cansüngü Koray ve Altunçekiç (2004) de fen bilimleri öğretmen adaylarının sınıf seviyeleri arttıkça öz-yeterlik inanç düzeylerinin yükseldiğini, ancak üçüncü ve dördüncü sınıf öğretmen adaylarının öz-yeterlik inançları arasında anlamlı bir farkın olmadığını tespit etmişlerdir.

Çalışmanın bulguları, erkek öğretmen adaylarının, kadın öğretmen adaylarına kıyasla öğretmen öz-yeterlik inancı ölçeğinden elde ettikleri ortalama puanların anlamlı düzeyde yüksek olduğunu ve bu anlamlı farklılığın sadece sınıf yönetimi alt boyutunda olduğunu ortaya koymaktadır. Bu durum, erkek öğretmen adaylarının kendilerini sınıf yönetiminde daha yeterli gördüklerini göstermektedir. Alanyazında öğretmenlerin öz-yeterlik inançları arasında cinsiyete göre farkın olduğunu ortaya koyan araştırmalar (örneğin Çalışkan, Selçuk ve Özcan, 2010; Demirtaş, Cömert ve Özer, 2011; Özenoğlu-Kiremit ve Gökler, 2010) kadar değişmediğini ortaya koyan çalışmalara da rastlanmaktadır (Akbaş ve Çelikkaleli, 2006; Azar, 2010; Harurluoğlu ve Kaya, 2009; Küçük, Altun ve Paliç, 2013; Özcan, 2017; Pas, Bradshaw ve Hershfeldt, 2012; Saracaloğlu ve Yenice, 2009; Yaman vd., 2004; Yenice, 2009). Bu durum, öğretmen öz-yeterlik inançlarını cinsiyet değişkeni açısından daha detaylı incelenmesi gerekliliğini ortaya koymaktadır.

Öğretmen adaylarının öz-yeterlik kaynaklarına yönelik bulgulara göre, katılımcıların doğrudan yaşantılar ve fizyolojik ve duygusal durum kaynağında çoğunlukla doğru, dolaylı yaşantı ve sözel ikna kaynağında ise genellikle doğru düzeyde olduğu saptanmıştır. Öğretmen adaylarının doğrudan yaşantılar boyutunda sergiledikleri yüksek düzeyler, onların öğretmenlik mesleğine ilişkin başarılı yaşantılar geçirdiklerini, kendilerini ders anlatma ve etkili öğrenme ortamı oluşturmada yetkin gördüklerini ortaya koymaktadır. Woolfolk Hoy ve Burke-Spero 
(2005) tarafindan yapılan boylamsal çalışmada doğrudan yaşantıların öğretmen adaylarının gelişiminde en etkili kaynak olduğu saptanmıştır. Öğretmen adayları, uygulamalı dersler kapsamında akranlarını ve öğretim üyelerini, okul deneyimi dersi kapsamında ise öğretmenleri gözlemleme firsatı edinmektedir. Elde edilen bulgulara dayalı olarak, öğretmen adaylarının yapmış oldukları bu gözlemlerin onların öz-yeterlik inançlarının gelişimini yüksek oranda etkilediği sonucuna ulaşmak mümkündür. Bu bulgu diğer çalışmalar tarafindan da tespit edilmiştir. Öğretmen adaylarının deneyimli öğretmenlerin videolarını izlemeleri (Bautista, 2011) veya öğretmenleri model almaları (Usher ve Pajares, 2008) onların dolaylı yaşantılar yoluyla deneyim kazanmalarına ve öz-yeterlik inançlarının gelişimlerine katkısı olmaktadır.

İnsanların davranışlarını etkileyebilmek için sözel ikna yöntemi oldukça yararlı bir yöntemdir. Bireylere, yeteneklerinin yetersiz olduğu konusunda sözel ikna uygulandığında bu bireylerin öz-yeterlikleri de düşük olabilir. Charalambous, Philippou ve Kyriakides (2008) alanda uzman olan kişilerin, öğretmen adaylarını hem model olarak hem de sözel dönütlerle etkilediklerini belirtilmiştir. Ancak, Usher ve Pajares (2008) ve Britner ve Pajares (2006) tek başına sözel ikna yoluyla edinilen öz-yeterlik inancının uzun süreli olmayabileceğini ve bu nedenle diğer kaynaklarla birlikte kullanıldığında etkili olabileceğini belirtmektedirler. Dolayısıyla, alanında uzman kişiler tarafından yeterliklerinin onaylanması ve bu onayın uzun süreli olması önemlidir. Çalışmanın bulguları da öğretmen adaylarının uzman olduklarını düşündükleri kişilerden yeterlikleri yönünde olumlu dönütler aldıklarında, kendi yeterliklerine olan inançlarının arttı̆̆ını ortaya koymaktadır.

Terleme, kayg1, yorgunluk gibi olumsuz faktörler, bireyi başarısız olma, küçük düşme korkusuyla karşı karşıya bırakacağından öz-yeterlik inancını düşürür. Fizyolojik ve duygusal durumların çok az veya çok fazla hissedilmesi öz-yeterlik inancını olumsuz etkilerken, orta düzeyde algılanması olumlu yönde etkilemektedir (Bandura, 1997). Çalışma sonuçlarına göre öğretmen adaylarının fizyolojik ve duygusal durumlar alt boyutunda sahip oldukları ortalama değer, onların duygusal korkulara sahip olduklarını göstermektedir. $\mathrm{Bu}$ nedenle, onların bu korku ve endişelerini ortadan kaldırmaya yönelik ortamların sağlanması gereklidir. Arslan (2019) da duygusal durumlarının öğretmen adaylarının öğretmenlik öz-yeterlik inançları üzerindeki etkisinin büyük olduğunu belirttiği çalışmasında öğretmenlik mesleğine ilişkin duygusal yaklaşımlarının artırılmasının önemini vurgulamaktadır. $\mathrm{Bu}$ nedenle, yüksek motivasyona sahip kişilerin bu mesleğe yönlendirilmesi gerektiğini, eğitim fakültelerinde öğretmenlik mesleğinin toplumda itibar gören bir meslek olduğunu öne çıkaran ve bu mesleğe karşı olumlu tutumların gelişmesini sağlayan yaklaşımların sergilenmesinin önemli olduğunu belirtmektedir (Arslan, 2019).

Çalışmadan elde edilen bulgular, öğretmen öz-yeterlik kaynakları ölçeğinin fizyolojik ve duygusal durumlar boyutu dışında tüm alt boyutlar için program türüne göre katılımcılar arasında anlamlı bir fark bulunduğunu göstermiştir. Betimsel istatistik sonuçlarına göre bulgular yorumlandığında fen bilimleri öğretmen adaylarının doğrudan yaşantılar, dolaylı yaşantılar ve sözel ikna alt boyutlarında anlamlı düzeyde yüksek ortalamaya sahip oldukları belirlenmiştir. Bu durumun, fen bilgisi öğretmenliği programında uygulamalı derslerin yoğun olmasından kaynaklandığı söylenebilir. Birinci sınıftan itibaren, özellikle gruplar halinde laboratuvar uygulamaları gerçekleştiren fen bilimleri öğretmen adayları lisans eğitiminin erken yıllarından itibaren öğrenme-öğretme faaliyetleri içinde olmaları onların kendi deneyimlerini yaşayabilmelerine olanak sağladığından öz-yeterliklerinin daha yüksek olduğu sonucu çıkarılabilir.

Sınıf düzeyi açısından öğretmen adaylarının öz-yeterlik kaynakları incelendiğinde doğrudan yaşantılar ve dolaylı yaşantılar alt boyutlarında 4. sınıf öğretmen adaylarının anlamlı düzeyde yüksek ortalamaya sahip oldukları saptanmıştır. Bu durum yapılan araştırmalarla da desteklenmektedir; okulda geçirilen zaman ile doğrudan yaşantılar kaynaklı öz-yeterlik 
inançları arasında ilişki tespit edilmiştir (Capa Aydin ve Woolfolk Hoy, 2005; Gurvitch ve Metzler, 2009). Sözel ikna ve fizyolojik ve duygusal durum boyutlarında ise sınıf düzeyleri açısından anlamlı fark tespit edilmemiştir; ancak dördüncü sınıf öğretmen adaylarının ortalamalarının daha yüksek olduğu saptanmıştır. Bu durumun, 4. sınıfta öğrenim gören öğretmen adaylarının uygulama okullarında elde ettikleri mesleki deneyim sonucunda kendilerini öğretmen olarak algılamaya başlamalarından kaynaklandığı düşünülmektedir.

Cinsiyet değişkeni açısından öğretmen adaylarının öz-yeterlik kaynaklarında anlamlı bir fark bulunmamıştır. Bu durum, cinsiyetin öz-yeterlik kaynakları üzerinde etkili olmadığını göstermektedir. O’Neil ve Stephenson (2012) ve Süzer (2019) de yaptıkları çalışmalarında benzer sonuçlara ulaşmışlardır.

Gerçekleştirilen çalışmanın sonuçlarına dayalı olarak bundan sonraki çalışmalar için bazı öneriler şu şekilde sıralanabilir. Farklı programlardan öğretmen adaylarının öz-yeterlik inançları ve öz-yeterlik kaynaklarını belirlemeye yönelik çalışmalar gerçekleştirilerek mevcut araştırmanın bulguları ile karşılaştırılabilir. Görev yapmakta olan ilköğretim matematik ve fen bilimleri öğretmenleri ile gerçekleştirilecek benzer çalışmalardan elde edilecek bulgulara dayalı olarak incelenen değişkenlerin kıdeme göre nasıl değiştiği test edilebilir. Mevcut çalışmada, katılımcılar kendi yeterliklerini nicel veri toplama araçları ile değerlendirmiştir. Öğretmen özyeterlikleri hakkında daha derinlemesine bilgi edinebilmek amaciyla nicel veriler nitel verilerle desteklenebilir. İleriki çalışmalarda, incelenen değişkenlerin kendi arasındaki ve akademik başarı gibi diğer değişkenlerle olan doğrudan ve dolaylı ilişkilerini test etmek için yapısal eşitlik modelleri kullanılabilir.

\section{Makalenin Bilimdeki Konumu \\ Matematik ve Fen Bilimleri Eğitimi Bölümü/Fen Bilgisi Eğitimi}

\section{Makalenin Bilimdeki Özgünlüğü}

Bir öğretmenin öz-yeterlik inancı birçok kaynak ve değişkenden etkilenmektedir. Örneğin, öz-yeterliği yüksek olan öğretmenler, öğretmenlik mesleğine yönelik olumlu tutum geliştirirler, öğrencilerin aktif olduğu öğrenme ortamları oluştururlar, motivasyonları yüksek ve daha başarılı öğrenciler yetiştirirler. Yapılan bu çalışma ile fen bilimleri ve ilköğretim matematik öğretmen adaylarının öz-yeterlik inançları ve öz-yeterlik kaynakları düzeylerinin belirlenmesi amaçlanmış ve öğrenim gördükleri program türü, sınıf düzeyi ve cinsiyet değişkenleri açısından nasıl değişiklik gösterdiği incelenmiştir. Bu çalışmayla, farklı program türündeki öğretmen adayları için öz-yeterlik inançlarının farklılaştığı ortaya konmuştur; öğretim stratejisi için dördüncü sınıf öğretmen adaylarının üçüncü sınıftakilerine kıyasla özyeterlik inançlarının daha yüksek olduğu tespit edilmiştir; sınıf yönetimi için erkek öğretmen adaylarının kadınlara kıyasla öz-yeterlik inançlarının daha yüksek olduğu belirlenmiştir; farklı program türündeki öğretmen adayları için öz-yeterlik kaynakları düzeylerinin farklılaştığı tespit edilmiştir; sınıf düzeyi arttıkça öğretmen adaylarının doğrudan ve dolaylı yaşantılarının daha yüksek olduğu pekiştirilmiştir.

\section{Kaynaklar}

Akbaş, A., ve Çelikkaleli, Ö. (2006). Sınıf öğretmeni adaylarının fen öğretimi öz-yeterlik inançlarının cinsiyet, öğrenim türü ve üniversitelerine göre incelenmesi. Mersin Üniversitesi Ĕ̈itim Fakültesi Dergisi, 2(1), 98-110.

Alrefaei, N.A. (2015). Teachers' sense of efficacy: Examining the relationship of teacher efficacy and student achievement. Unpublished Dissertation. University of Arkansas. 
Allinder, R.M. (1994). The relationship between efficacy and the instructional practices of special education teachers and consultants. Teacher Education and Special Education, 17(2), 86-95.

Aloe, A.M., Amo, L.C., \& Shanahan, M.E (2014). Classroom management self-efficacy and burnout: A multivariate meta-analysis. Educational Psychology Review 26(1), 101-126.

Arslan, Ş. (2019). Öğretmen adaylarının öğretmenlik meslĕ̆ine ilişkin öz yeterlik inancı kaynakları ve öz yeterlik inançlarının ögretmenlik mesleğine yönelik tutumlarına etkisi. Yayınlanmamış yüksek lisans tezi. Zonguldak Bülent Ecevit Üniversitesi, Zonguldak.

Azar, A. (2012). Ortaöğretim fen bilimleri ve matematik öğretmeni adaylarının öz yeterlilik inançlar1. Uluslararası Yönetim İktisat ve İşletme Dergisi, 6(12), 235-252.

Bandura, A. (1986). Social foundations of thought and action: a social cognitive theory. Englewood Cliffs: Prentice Hall.

Bandura, A. (1997). Self-efficacy: The exercise of control. New York: Freeman.

Bautista, N.U. (2011). Investigating the use of vicarious and mastery experiences in influencing early childhood education majors' self-efficacy beliefs. Journal of Science Teacher Education, 22, 333-349.

Britner, S.L., \& Pajares, F. (2006). Sources of science self-efficacy beliefs of middle school students. Journal of Research in Science Teaching, 43(5), 485-499.

Browne, M.W., \& Cudeck, R. (1993). Alternative ways of assessing model fit. In K.A. Bollen \& J.S. Long (Eds.), Testing structural equation models (pp. 136-162). Newbury Park, CA: Sage.

Capa Aydin, T., \& Woolfolk Hoy, A. (2005). What predicts teacher self-efficacy? Academic Exchange Quarterly, 9(4), 123-128.

Carleton, L.E., Fitch, J.C., \& Krockover, G.H. (2008). An in-service teacher education program's effect on teacher efficacy and attitudes. The Educational Forum, 72(1), 4662.

Charalambous, C.Y., Philippou, G.N., \& Kyriakides, L. (2008). Tracing the development of preservice teachers' efficacy beliefs in teaching mathematics during fieldwork. Educational Studies in Mathematics, 67(2), 125-142.

Cheung, H.Y. (2008) Teacher Efficacy: A comparative study of Hong Kong and Shanghai primary in- service teachers. The Australian Educational Researcher, 35(1), 103-123.

Clark, S., \& Newberry, M. (2019). Are we building preservice teacher self-efficacy? A largescale study examining teacher education experiences. Asia-Pacific Journal of Teacher Education, 47(1), 32-47.

Cohen J. (1988). Statistical power analysis for the behavioral sciences. New York, NY: Routledge.

Çalışkan, S., Selçuk, G.S., ve Özcan, Ö. (2010). Fizik öğretmen adaylarının öz-yeterlik inançları: Cinsiyet, sınıf düzeyi ve akademik başarının etkileri. Kastamonu Eğitim Dergisi,18(2), 449-466.

Çapa, Y., Çakıroğlu, Ç., ve Sarıkaya, H. (2005). Öğretmen özyeterlik ölçeği Türkçe uyarlamasının geçerlik ve güvenirlik çalışması. Ĕgilim ve Bilim, 10(117), 74-81.

Çapa-Aydın, Y., Uzuntiryaki-Kondakçı, E., Temli, Y., ve Tarkın, A. (2013). Adaptation of sources of self-efficacy inventory into Turkish. İlkögretim Online, 12(3), 749-758.

Demirtaş, H., Cömert, M., ve Özer, N. (2011). Öğretmen adaylarının özyeterlik inançları ve öğretmenlik mesleğine ilişkin tutumları. Ĕ̈itim ve Bilim, 36(159), 96-111.

Devos, C., Dupreiz, V., \& Paquay, L. (2012). Does the social working environment predict beginning teachers' self-efficacy and feelings of depression? Teaching and Teacher Education, 28, 206-217. 
Fives, H., \& Looney, L. (2009). College instructors' Sense of teaching and collective efficacy. International Journal of Teaching and Learning in Higher Education, 20(2), 182-191.

Fraenkel, J.R., Wallen, N.E., \& Hyun, H.H. (2011). How to design and evaluate research in education (8th Eds.). New York: McGraw-Hill.

Gurvitch, R., \& Metzler, M.W. (2009). The effects of laboratory-based and field-based practicum experience on pre-service teachers' self-efficacy. Teaching and Teacher Education, 25, 437-443.

Harurluoğlu, Y., ve Kaya, E. (2009). Biyoloji öğretmen adaylarının biyoloji öğretimine yönelik öz-yeterlik inançları. Ĕgitim Fakültesi Dergisi, 22(2), 481-496.

Henson, R. K. (2002). From adolescent angst to adulthood: Substantive implications and measurement dilemmas in the development of teacher efficacy research. Educational Psychologist, 37, 137-150.

Holzberger, D., Philipp, A., \& Kunter, M. (2013). How teachers' self-efficacy is related to instructional quality: A longitudinal analysis. Journal of Educational Psychology, 105(3), 774-786.

Jöreskog, K., \& Sörbom, D. (1993). Structural equation modeling with the SIMPLIS command language. Hillsdale, NJ: Erlbaum.

Kieffer, K.M., \& Henson, R.K. (2000, April). Development and validation of the sources of self-efficacy inventory (SOSI): Exploring a new measure of teacher efficacy. Paper presented at the annual meeting of the National Council on Measurement in Education, New Orleans, LA.

Klassen, R. M., \& Chiu, M.M. (2010). Effects on teachers' self-efficacy and job satisfaction: Teacher gender, years of experience, and job stress. Journal of Educational Psychology, 102, 741-756.

Klassen, R.M., Tze, V.M.C., Betts, S.M., \& Gordon, K.A. (2011). Teacher efficacy research 1998-2009: Signs of progress or unfulfilled promise? Educational Psychology Review, 23, 21-43.

Kline, R.B. (2005). Principles and practice of structural equation modeling (2nd Eds.). New York: Guilford Press.

Küçük, M., Altun, E., ve Paliç, G. (2013). Sınıf öğretmenlerinin fen öğretimi öz-yeterlik inançlarının incelenmesi: Rize ili örneklemi. Amasya Üniversitesi Ĕ̌̆itim Fakültesi Dergisi, 2(1), 45-70.

Lortie, D.C. (1975). Schoolteacher: A sociological study. Chicago, IL: University of Chicago Press.

Lumpe, A., Czerniak,C., Haney, J., \& Beltyukova, S. (2012). Beliefs about teaching science: the relationship between elementary teachers' participation in professional development and student achievement. International Journal of Science Education, 34(2), 153-166.

McDonnough, J.T., \& Matkins, J.J. (2010). The role of field experience in elementary preservice teachers' self-efficacy and ability to connect research to practice. School Science and Mathematics, 110(1), 13-23.

Milner, H.R. (2002). A case study of an experienced English teacher's self-efficacy and persistence through "crisis" situations: Theoretical and practical considerations. High School Journal, 86, 28-35.

Morris-Rothschild, B.K., \& Brassard, M.R. (2006). Teachers' conflict management styles: The role of attachment styles and classroom management efficacy. Journal of School Psychology, 44(2), 105-121.

Morris, D.B., Usher, E.L., \& Chen, J.A. (2017). Reconceptualizing the sources of teaching selfefficacy: A critical review of emerging literature. Educational Psychology Review, 29, 795-833. 
O’Neil, S., \& Stephenson, J. (2012). Exploring Australian pre-service teachers sense of efficacy, its sources, and some possible influences. Teaching and Teacher Education, 28(4), 535-545.

Özcan, C. (2017). Fen bilgisi ögretmen adaylarının mesleki özyeterlik inançları ve ögretmenlik mesleğine yönelik tutumları ile ilköğretim bölümlerinin karşılaştırılması. Yayınlamamış yüksek lisans tezi. Akdeniz Üniversitesi, Antalya.

Özenoğlu-Kiremit, H., ve Gökler, İ. (2010). Fen bilgisi öğretmenliği öğrencilerinin biyoloji öğretimi ile ilgili öz-yeterlik inançlarının karşılaştırılması. Pamukkale Üniversitesi Eğitim Fakültesi Dergisi, 27, 41-54.

Partnership for 21st Century Learning [P21] (2007). Framework for 21st Century Learning. (http://static.battelleforkids.org/documents/p21/P21 framework 0816 2pgs.pdf,

Erişim tarihi: 20.08.2020)

Palmer, D.H. (2006). Sources of self-efficacy in a science methods course for primary teacher education students. Research in Science Education, 36, 337-353.

Pallant, J. (2010). SPSS Survival Manual: A step by step guide to data analysis using SPSS (4th Eds.). London: McGraw Hill Companies.

Pas, E.T., Bradshaw, C.P., \& Hershfeldt, P.A. (2012). Teacher-and school-level predictors of teacher efficacy and burnout: Identifying potential areas for support. Journal of School Psychology, 50(1), 129-145.

Posnanski, T. J. (2002). Professional development programs for elementary science teachers: An analysis of teacher self-efficacy beliefs and a professional development model. Journal of Science Teacher Education, 13, 189-220.

Ruble, L.A., Usher, E. L., \& McGrew, J.H. (2011). Preliminary investigation of the sources of self-efficacy among teachers of students with autism. Focus on Autism and Other Developmental Disabilities, 26, 67-74.

Sabbe, E., \& Aelterman, A. (2007). Gender in teaching: A literature review. Teachers and Teaching: Theory and Practice, 13, 521-538.

Salanova, M., Llorens, S., \& Schaufeli, W.B. (2011). Yes, I can, I feel good \& I just do it! On gain cycles and spirals of efficacy beliefs, affect, and engagement. Applied Psychology: An International Review, 60, 255-285.

Saracaloğlu, A.S., ve Yenice, N. (2009). Fen bilgisi ve sinıf öğretmenlerinin öz yeterlik inançlarının bazı değişkenler açısından incelenmesi. Eğitimde Kuram ve Uygulama, 5(2), 244-260.

Süzer, B. (2019). Fen bilimleri ögretmenlerinin öz-yeterlik inançları ile öz-yeterlik kaynakları arasındaki ilişkinin incelenmesi: Tokat ili örneği. Yayımlanmamış yüksek lisans tezi. Tokat Gaziosmanpaşa Üniversitesi Eğitim Bilimleri Enstitüsü, Tokat.

Şenler, B. (2011). Pre-service science teachers' self-efficacy in relation to personality traits and academic self-regulation. Yayımlanmamış doktora tezi. ODTÜ, Ankara.

Tabachnick, B.G., \& Fidell, L.S. (2007). Using multivariate statistics (5th Eds.). New York: Allyn \& Bacon/Pearson Education.

Tschannen-Moran, M., \& Johnson, D. (2011). Exploring literacy teachers’ self-efficacy beliefs: Potential sources at play. Teaching and Teacher Education, 27, 751-761.

Tschannen-Moran, M., \& Woolfolk Hoy, A. (2001). Teacher efficacy: Capturing an elusive construct. Teaching and Teacher Education, 17, 783-805.

Tschannen-Moran, M., \& Woolfolk Hoy, A. (2007). The differential antecedents of selfefficacy beliefs of novice and experienced teachers. Teaching and Teacher Education, 23, 944-956.

Tschannen-Moran, M., Woolfolk Hoy, A., \& Hoy, W. K. (1998). Teacher efficacy: Its meaning and measure. Review of Educational Research, 68(2), 202-248. 
Usher, E.L., \& Pajares, F. (2008). Sources of self-efficacy in schools: Critical review of the literature and future directions. Review of Educational Research, 78, 4, 751-796.

Utley, J., Moseley, C., \& Bryant, R. (2005). Relationship between science and mathematics teaching efficacy of preservice elementary teachers. School Science and Mathematics, 105(2), 82-87.

Wolters, C.A., \& Daugherty, S.G. (2007). Goal structures and teachers' sense of efficacy: Their relation and association to teaching experience and academic level. Journal of Educational Psychology, 99(1), 181-193.

Woolfolk Hoy, A., \& Burke-Spero, R. (2005). Changes in teacher efficacy during the early years of teaching: A comparison of four measures. Teacher and Teacher Education, 21, 343-356.

Wyatt, M. (2014). Towards a re-conceptualization of teachers' self-efficacy beliefs: Tackling enduring problems with the quantitative research and moving on. International Journal of Research and Method in Education, 37(2), 166-189.

Yaman, S., Cansüngü Koray, Ö., ve Altunçekiç, A. (2004). Fen bilgisi öğretmen adaylarının öz-yeterlik inanç düzeylerinin incelenmesi üzerine bir araştırma. Türk Eğitim Bilimleri Dergisi, 2(3), 355 - 366.

Yenice, N. (2009). Search of science teachers' teacher efficacy and self-efficacy levels relating to science teaching for some variables. Procedia-Social and Behavioral Sciences, 1(1), 1062-1067.

Zee, M., \& Koomen, H.M. (2016). Teacher self-efficacy and its effects on classroom processes, student academic adjustment, and teacher well-being: A synthesis of 40 years of research. Review of Educational Research, 86(4), 981-1015.

\section{Summary \\ Statement of Problem}

Teachers who have high self-efficacy tend to be open to innovations, are willing to use more contemporary teaching strategies in classroom environments, possess high level of lesson planning and implementation skills, are successful in enabling student participation in their lesson, are aware of learning outcomes and play an active role for students in achieving these outcomes, and are highly committed to their profession and are unlikely exhausted in (Allinder, 1994; Aloe, Amo, \& Shanahan, 2014; Holzberger, Philipp, \& Kunter, 2013; Tschannen-Moran, Woolfolk Hoy, \& Hoy, 1998; Tschannen-Moran \& Woolfolk Hoy, 2001; Zee \& Koomen, 2016). Thus, it is crucial to determine teachers' self-efficacy beliefs and the factors affecting these beliefs.

Considering self-efficacy as an essential teacher characteristic for effective teaching and learning, researchers have directed their attention to teacher self-efficacy since the 1970s. Even though there are many research studies on in-service and pre-service teachers' self-efficacy beliefs, there are a few studies related to sources of these beliefs in the current literature (Henson, 2002; Tschannen-Moran, Woolfolk Hoy, \& Hoy, 1998). Thus, the aim of this study was to determine the levels of self-efficacy beliefs and sources of these beliefs of pre-service science and elementary mathematics teachers, and investigate whether these beliefs and their sources differ according to the program type, grade level and gender.

\section{Method}

In this study, the survey design, one of the non-experimental quantitative research approaches, was used. The study sample consisted of 885 (445 science, 440 elementary mathematics) pre-service teachers who were enrolled in the third and fourth grades of Science Education and Elementary Mathematics Education programs of five universities in Turkey. The convenience sampling method was used to select the participants. Two measuring instruments 
were utilized: Teachers’ Sense of Efficacy Scale (TSES) and Sources of Self-Efficacy Inventory (SOSI). The descriptive statistics were used to investigate the levels of self-efficacy beliefs and its sources according to the program type, grade level, and gender. To find out whether selfefficacy beliefs (for the linear combination of three dimensions) and its sources (for the linear combination of four dimensions) differ with respect to program type, grade level and gender, six separate one-way Multivariate Analysis of Variance (MANOVA) were computed.

\section{Findings and Discussions}

The results of the descriptive statistics revealed that the mean values for the subscale scores of the TSES were all found at the sufficient level, whereas the mean values for the subscale of the SOSI were found at the different levels.

Multivariate Tests showed that the mean scores of pre-service science teachers are significantly higher than that of elementary mathematics teachers for all subscales of TSES. This result contradicts the findings of Özcan (2017), Alrefaei (2015), and Azar (2010). Results also showed that the mean scores of fourth graders are significantly higher than that of third graders for only the Instructional Strategies subscale. This can be because of fourth grade preservice teachers having school practices in their last year of the program. Moreover, the mean scores of males are significantly higher than that of females for only the Classroom Management subscale. In the literature, there are contradictory results in this.

As for the sources of self-efficacy beliefs, it was found that the mean scores of preservice science teachers are significantly higher than that of elementary mathematics teachers for four subscales of the SOSI, except the Psychological and Emotional Arousal subscale. This can be since pre-service science teachers have much more teaching practices through laboratory courses in their program. It was also found that the mean scores of fourth graders are significantly higher than that of third graders for the Mastery Experience and Vicarious Experience subscales. This result is supported by Capa Aydin and Woolfolk Hoy (2005), and Gurvitch and Metzler (2009). Lastly, there are no statistically significant gender differences for any of the subscales of the SOSI. This result is consistent with the findings of O'Neil and Stephenson (2012), and Süzer (2019).

\section{Conclusions and Recommendations}

In light of the findings obtained through this study, it can be concluded that the preservice teachers who participated in the study had a high sense of efficacy for classroom management, student engagement, and instructional strategies. Besides, the levels of teacher self-efficacy of pre-service teachers change by program type, grade level, and gender. In terms of the sources of teacher self-efficacy, it can be stated that mastery experience and psychological and emotional arousal sources are more influential than vicarious experience and verbal persuasion in the development of their self-efficacy beliefs. Furthermore, the levels of sources of self-efficacy beliefs vary by program type and grade level but not by gender.

Further research should be carried out to examine how pre-service teachers' selfefficacy beliefs and four sources of these beliefs change over time and promote self-efficacy beliefs. These efforts would be helpful in better understanding of how teacher self-efficacy beliefs are developed. 